\title{
Lynx habitat suitability in and near Voyageurs National Park
}

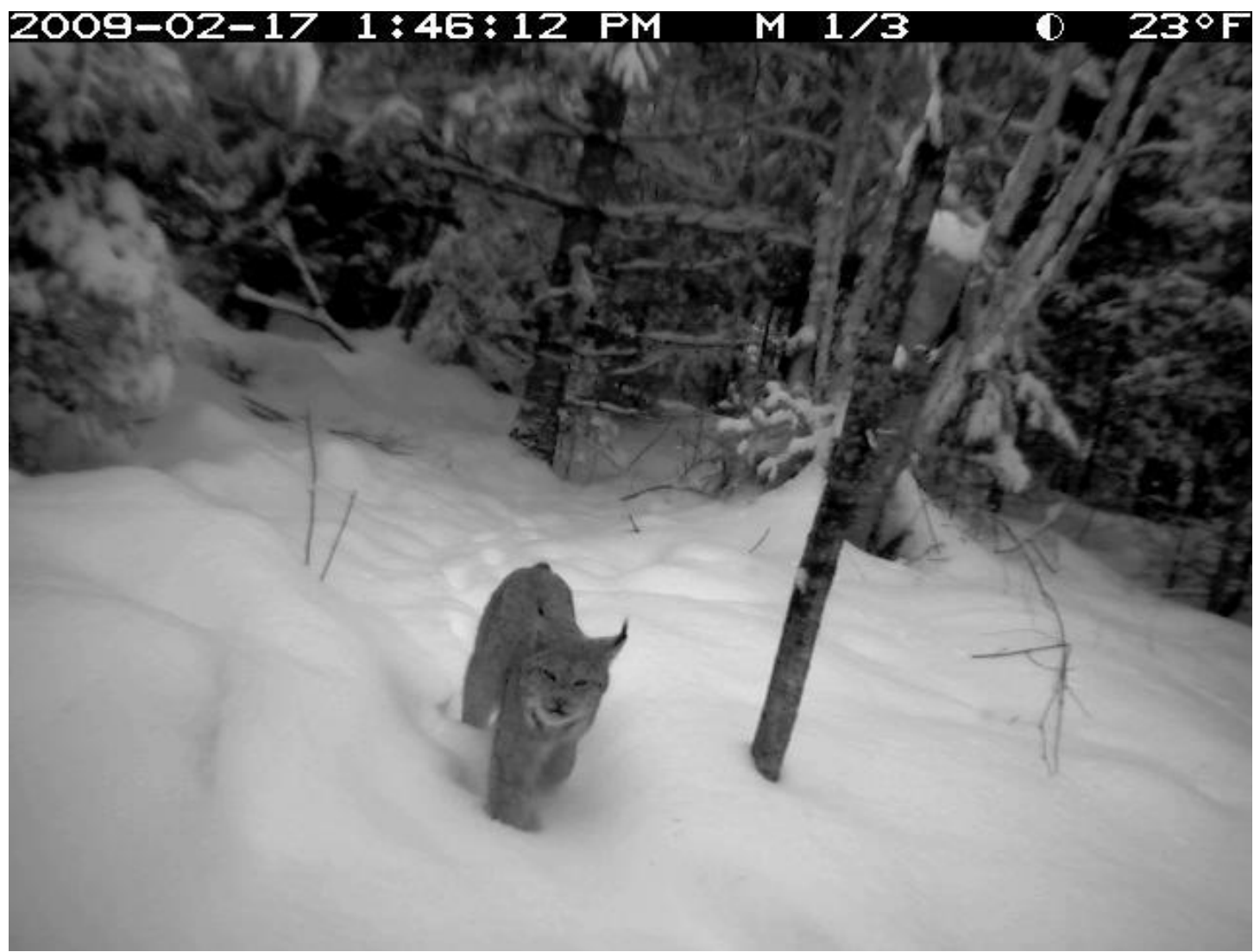

Ron Moen, Ph.D.

Center for Water and Environment Natural Resources Research Institute University of Minnesota Duluth 5013 Miller Trunk Highway Duluth, MN 55811-1442
Steven K. Windels, Ph.D.

Resource Management Division Voyageurs National Park 3131 Highway 53

International Falls, MN 56649

NRRI Technical Report No. NRRI/TR-2009/19, Release 1.0

Please contact rmoen@ nrri.umn.edu before citing as manuscripts are in review and in preparation If corrections are made to this technical report they will be posted at www.nrri.umn.edullynx 


\begin{abstract}
Voyageurs National Park (VOYA) is within historical distribution limits of Canada lynx (Lynx canadensis). Records of lynx exist for the area in and near VOYA since the 1970s, and recent sightings have been confirmed with DNA analysis. We initiated this project to determine habitat suitability for lynx in VOYA, and if possible to deploy radiocollars on lynx in VOYA. The lynx radiotelemetry project on the Superior National Forest provided data on home range size, density, cover type use, and prey density to which VOYA could be compared. We used remote cameras and snow-tracking to search for lynx in and near VOYA in 2007 and 2008. We estimated density of the lynx's primary prey, snowshoe hare (Lepus americanns) with hare pellet counts, extrapolated hare density to the landscape level, and contrasted VOYA with lynx home ranges from the Superior National Forest radiotelemetry project. Remote cameras and track searches did not provide evidence to suggest there were resident lynx in VOYA. No lynx were seen in pictures taken at camera stations where other carnivore species were photographed during this project. We did not positively identify any tracks to be from lynx. The hare pellet data indicated that VOYA and the surrounding area may not be good habitat for lynx at the present time. Hare pellet densities in core areas of lynx home ranges in northeastern Minnesota were 1.5 to 2.0 times higher than hare pellet densities in and near VOYA. If hare density were to increase in or near VOYA, at least 3 to 4 female lynx home ranges and 2 male lynx home ranges could fit in VOYA and the surrounding area. Although there may be local areas of high hare density a lynx could use for a short period, it does not appear that there are currently resident lynx in VOYA given the search effort over the past seven years. Lynx documented on and near VOYA are probably transient animals.
\end{abstract}




\section{Table of Contents}

Summary Error! Bookmark not defined.

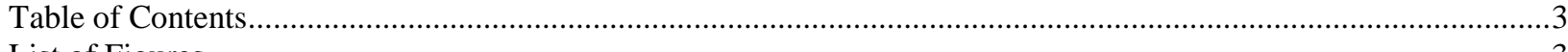

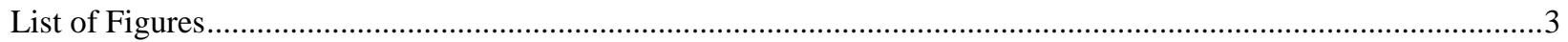

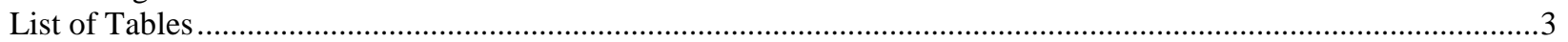

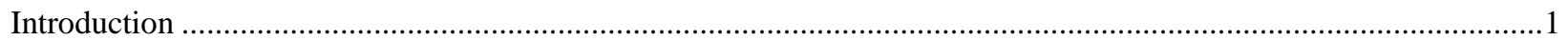

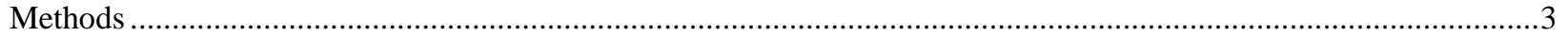

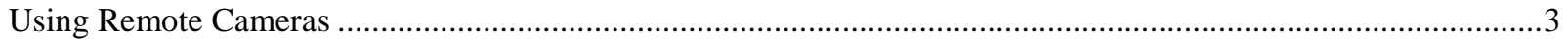

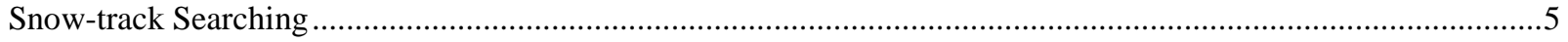

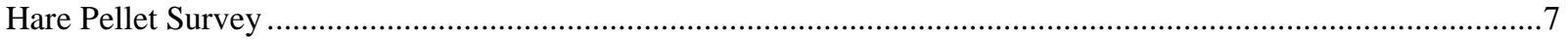

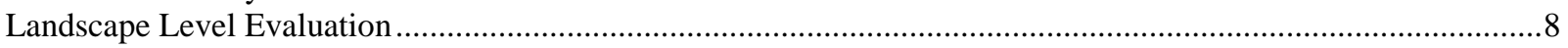

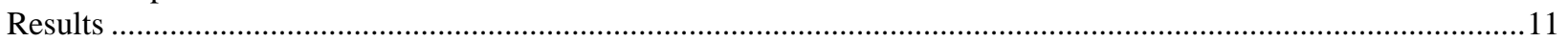

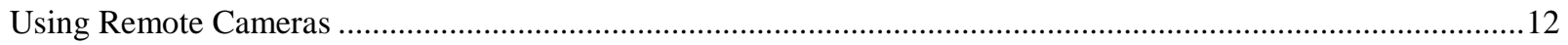

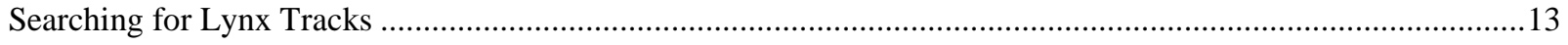

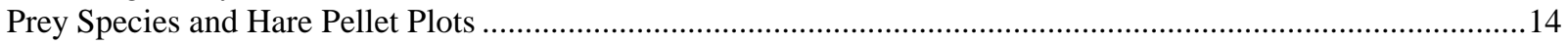

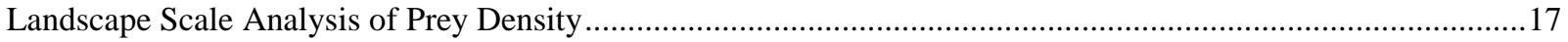

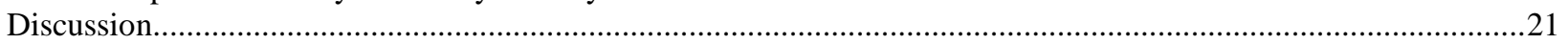

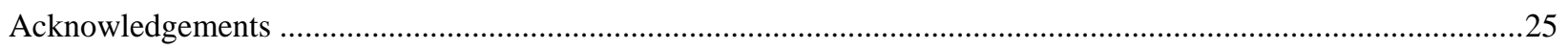

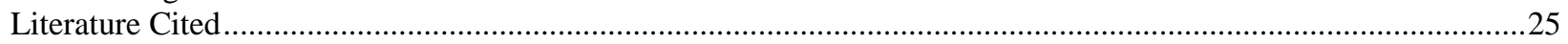

\section{List of Figures}

Figure 1. Map of take records on non-radiocollared lynx, sightings records and historical records. ...........................1

Figure 2. Lynx locations from the Superior National Forest radiotelemetry project. .................................................2

Figure 3. Camera locations used in VOYA and adjacent lands.......................................................................

Figure 4. Roads and trails used for the snow track survey routes in VOYA and adjacent lands...............................6

Figure 5. Hare pellet survey plots established in VOYA and the adjacent area. ......................................................

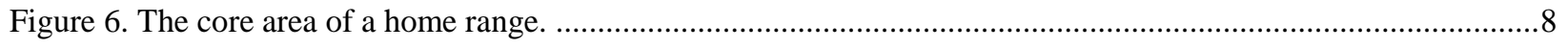

Figure 7. Example of random points in VOYA, the $10 \mathrm{~km}$ buffer strip, and the $20 \mathrm{~km}$ buffer strip.........................

Figure 8. The $10 \mathrm{~km}$ and $20 \mathrm{~km}$ buffer strips around VOYA and the composite lynx home ranges.........................10

Figure 9. Locations of snow-tracking, camera stations, and hare pellet plot transects. ............................................11

Figure 10. Contrasting measurement of cleared and uncleared plots.. …................................................................14

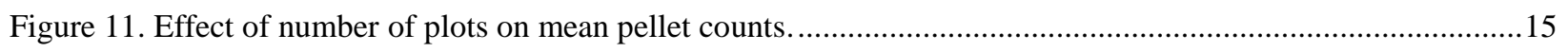

Figure 12. Randomly placed circular areas corresponding to a lynx core area that were sampled............................17

Figure 13. Predicted suitable denning habitat in northeastern Minnesota and VOYA. ...........................................20

Figure 14. Approximate size of lynx home ranges (male and female) relative to VOYA.........................................21

\section{List of Tables}

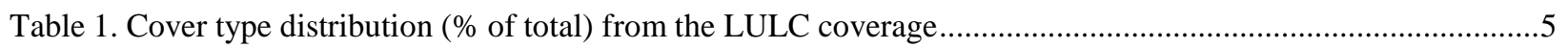

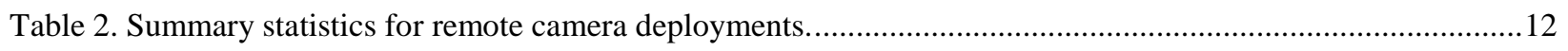

Table 3. Summary statistics for carnivore tracks per day since last snowfall.............................................................13

Table 4. Regression parameters for comparison of pellet counts in cleared and uncleared plots..............................15

Table 5. Hare pellet density (mean pellets $/ \mathrm{m}^{2}$ ) in LULC cover types in VOYA and the adjacent area. ..................16

Table 6. Cover type composition and weighted mean hare pellet density in LULC cover types. ..............................16

Table 7. Predicted pellet density in $0.3 \mathrm{~km}^{2}, 3.1 \mathrm{~km}^{2}$, and $25 \mathrm{~km}^{2}$ circles.......................................................18

Table 8. Differences in cover type area in VOYA, and in 10 and $20 \mathrm{~km}$ donuts around VOYA.............................19

Table 9. Differences in cover type area in $25 \mathrm{~km}^{2}$ circles in each area. ..............................................................20 


\section{Introduction}

The Canada lynx (Lynx canadensis) is found in the boreal forests of Canada and the northern United States. Lynx populations in Canada increase and decrease with populations of the snowshoe hare (Lepus americanus) over an approximate 10-year period (Elton \& Nicholson, 1942; Keith, 1978; Krebs et al., 2001). Lynx occur at a density of $<3 / 100 \mathrm{~km}^{2}$ during periods of hare scarcity in northern Canada and at densities > $30 / 100 \mathrm{~km}^{2}$ during peak hare years (Poole, 1994; Slough \& Mowat, 1996). Throughout this predator-prey cycle lynx populations lag 1-2 years behind hare populations (Brand et al., 1976; O'Donoghue et al., 1997; Poole, 1994; Slough \& Mowat, 1996).

Minnesota is at the southern edge of Canada lynx range. Voyageurs National Park (VOYA) is within historical distribution limits of lynx (McKelvey et al., 2000), and is also within estimated range of lynx in Minnesota in the 1970s (Henderson, 1978). Records of lynx exist for the area in and near VOYA since the 1970s (Fig. 1). Lynx have been present in Minnesota since the beginning of a radiotelemetry study initiated in northeastern Minnesota in 2003, and at least 10 litters were born to radiocollared females (Moen, 2009; Moen et al., 2008a; Moen et al., 2008b). Trapping effort and lynx locations for the Superior National Forest radiotelemetry study was primarily in eastern St. Louis, Lake, and Cook counties (Fig. 2). Lynx may have been present in western St. Louis County and Koochiching County (including VOYA) but these lynx would not have been radiocollared because the radiotelemetry study trapping effort was focused in the eastern part of northeastern Minnesota.

Figure 1. (left) Map of take (recent mortality or incidental take) records on non-radiocollared lynx, sightings records from the MN DNR sightings database, and historical records (McKelvey et al., 2000). (right) Township level records of lynx in Minnesota in the 1970s (Henderson, 1978).
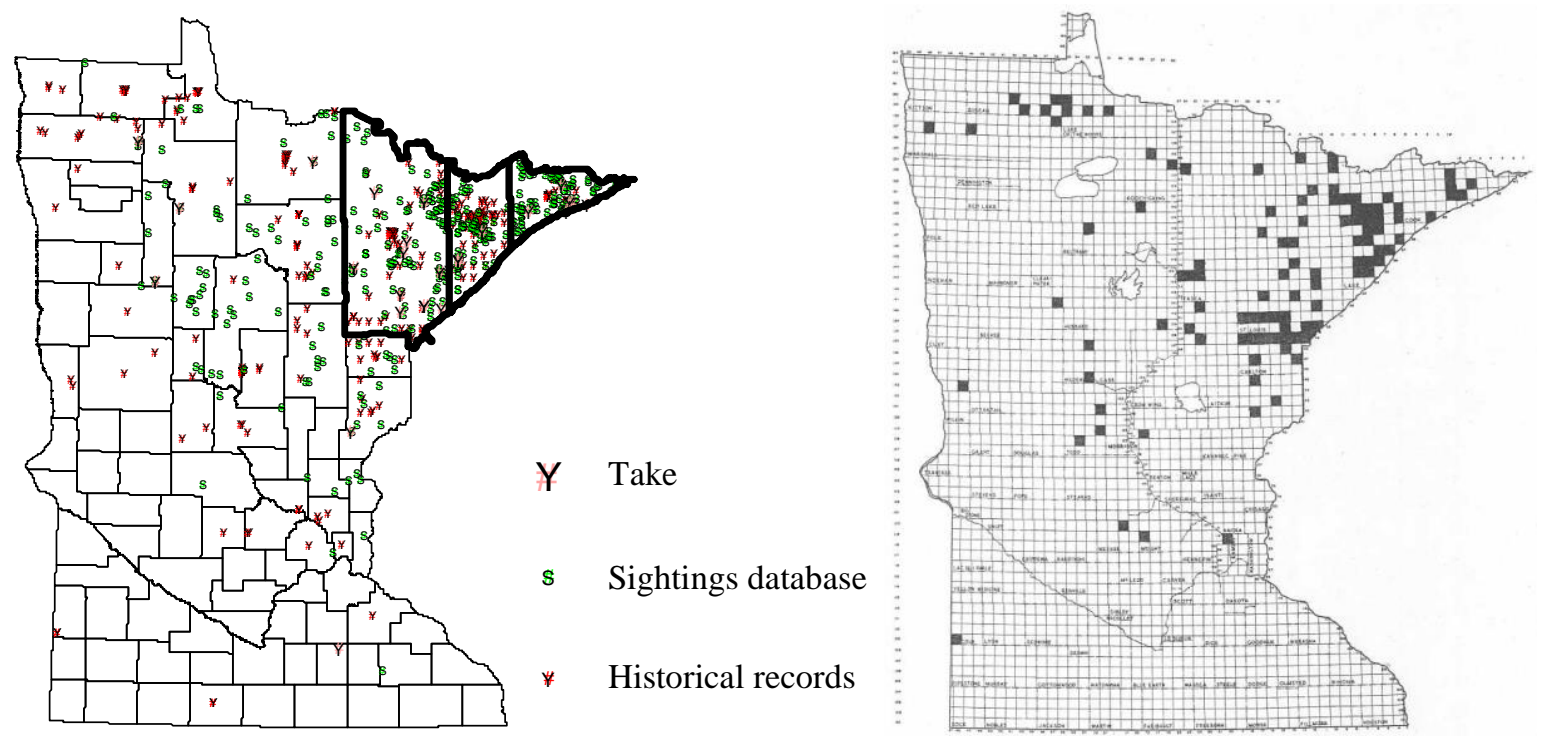
Snowshoe hare densities in Minnesota are higher than the lowest hare densities typically found in Canada, but are less than $10 \%$ of peak hare density in northern Canada (Moen et al., 2008b). Home ranges of radiocollared lynx in northeastern Minnesota are similar in size to home ranges of other lynx populations in the U.S. (Burdett et al., 2007). About 25\% of northeastern Minnesota contains areas of predicted higher quality hare habitat (McCann \& Moen, 2010; McCann, 2006) that also corresponds to area classified as better lynx denning habitat (Moen et al., 2008a). A population of up to 200 lynx could be supported at a density of $<3 / 100 \mathrm{~km}^{2}$ when $25 \%$ of northeastern Minnesota is suitable habitat (Moen, 2009; Moen et al., 2008b). Lynx are also harvested in the Ontario Ministry of Natural Resources (OMNR) districts closest to VOYA (Fig. 2).

Figure 2. Lynx locations from the radiotelemetry project (yellow symbols) overlaid on a map showing VOYA and trapping districts in Ontario. Harvest data from Ontario is courtesy of the Ontario MNR. Shown on the figure is the average harvest (lynx/1,000 $\mathrm{km}^{2}$ ) from 1991 to 2004 within each of the districts near northeastern Minnesota. Cook, Lake, and St. Louis Counties are shaded light green.

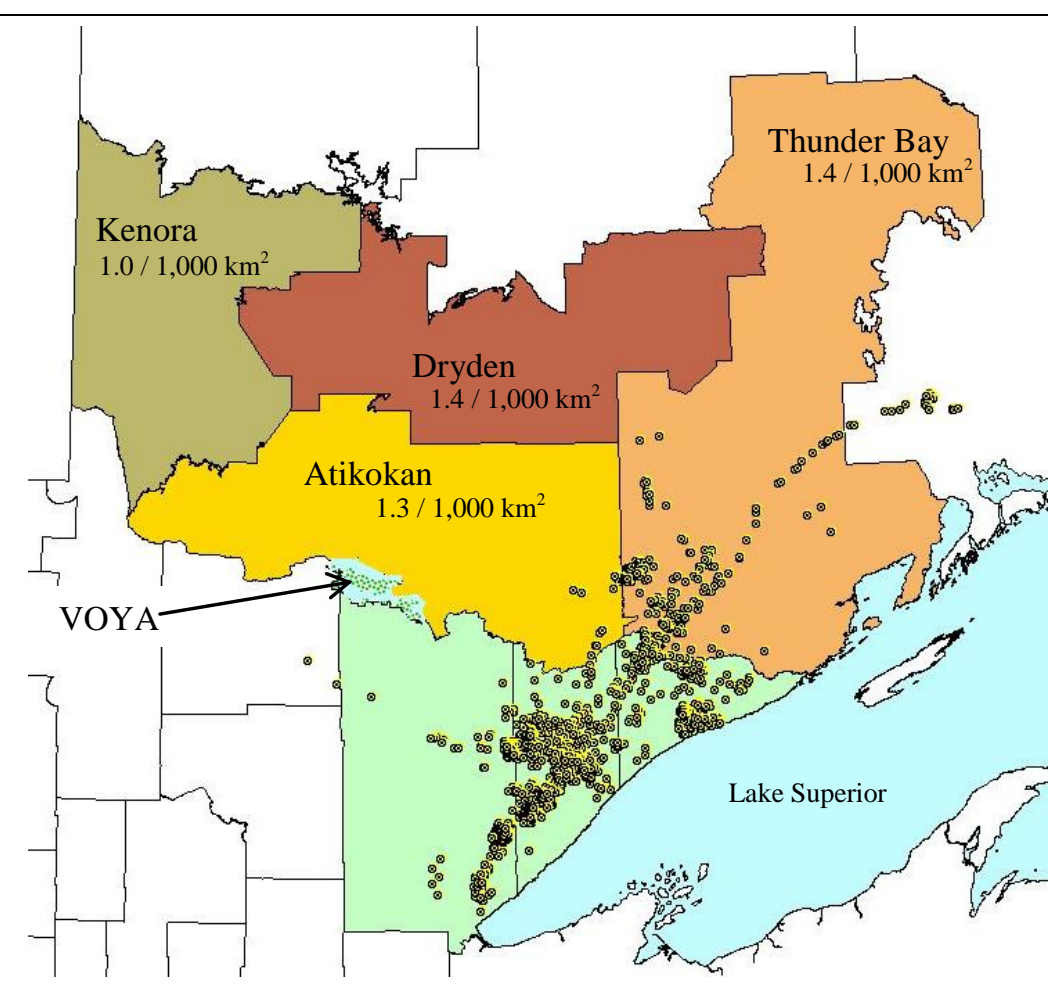

VOYA was searched for lynx between 2001 and 2004 with implementation of the National Lynx Detection Protocol (NLDP) in 2001 and 2002 at 250 sites for more than 7,000 exposure days (Route et al., 2009). No confirmations of lynx presence occurred with the NLDP. However, the NLDP method does not appear useful for detecting lynx presence in the Great Lakes region as lynx hairs were not found on NLDP hair snares in the middle of known lynx home ranges in Minnesota (Burdett et al., 2006). Several lynx sightings, which were not confirmed, were reported to VOYA staff in the early 2000s, and two lynx were documented in VOYA based on tracks and DNA analysis of scats collected in 2004 (Route et al., 2009). 
We initiated this project to determine habitat suitability for lynx in VOYA, and to deploy radiocollars on any lynx found in VOYA. The lynx radiotelemetry project focused on the Superior National Forest provided data on home range size, density, cover type use, and prey density to which VOYA could be compared (Moen, 2009; Moen et al., 2008b). The initial objectives of the VOYA project were to use a combination of techniques (snowtracking, DNA analysis, live trapping, remote cameras, and telemetry) to estimate the number of resident and transient lynx in VOYA and bordering areas, to estimate habitat use patterns of radiocollared individuals, and to document reproduction if adult females were radiocollared. Because lynx presence was not confirmed in the initial year of project, we added the objectives of estimating prey density with pellet counts and extrapolating hare density to the landscape level to contrast VOYA covertypes with areas of lynx home ranges from the radiotelemetry project.

\section{Methods}

Field work on this project included using remote cameras in and near VOYA, searching for lynx tracks on vehicle and on snowshoe, and counting snowshoe hare pellets in plots. Cameras and snowshoe hare pellet plots were randomly placed, with restrictions to insure that plots were located in different cover types and were logistically possible to reach. Plot locations were based on cover classes derived from LandSat imagery (LULC) by the Manitoba Remote Sensing Centre for the MN DNR in the 1990's (MN DNR, 1998). The LULC includes coverage of both VOYA and the study area of the lynx radiotelemetry project in the Superior National Forest. The LULC was previously used to identify areas of predicted higher quality hare habitat (McCann, 2006; McCann \& Moen, 2010) that also roughly corresponds to area classified as better lynx denning habitat (Moen et al., 2008a). We also used GIS analysis to place hare pellet counts in a spatial context that could be compared to hare pellet counts in areas used by radiocollared lynx in NE MN (Fig. 2).

\section{Using Remote Cameras}

We deployed remote cameras in VOYA and within a $10 \mathrm{~km}$ buffer strip to the south of VOYA. Cameras were not deployed in Ontario. Cameras were deployed in the Deciduous, Coniferous, Mixed Forest, Regenerating Forest and Wetland Bog cover types that represent about $84 \%$ of VOYA and 95\% of the landscape within a $20 \mathrm{~km}$ buffer strip of VOYA (Table 1). We deployed cameras in cover types where we would expect lynx to be present, and also in other cover types that lynx or other carnivore species could use. Locations for camera stations were generated in ArcView 3.3. We first created 250 random locations, removed locations on open water, and removed locations more than $750 \mathrm{~m}$ from a shoreline, trail, or road. Finally, we excluded locations that were on or within $250 \mathrm{~m}$ of private lands, ending with 50 potential camera stations (Fig. 3). The majority of camera locations were concentrated outside of VOYA's ownership 
for two primary reasons: 1) the Regenerating Forest cover type that is an important component of lynx home ranges (Moen et al., 2008) is rarely found in VOYA, and 2) few roads and trails occur within VOYA while extensive snowmobile trail networks exist adjacent to park boundaries. Although the LULC coverage was the primary coverage used, we also tried to distribute points to include representative cover types in the Upper Midwest Gap Analysis Program coverage (MN DNR 1996), and the USGS-NPS VOYA cover type map (USGS 2001). The VOYA cover type map was completed in 2001 and is used for ecological planning in the park.

Figure 3. Camera locations used in VOYA and adjacent lands. Locations outside of VOYA were on public lands and included LULC cover types that were not common in VOYA (e.g., Regenerating Forest ) where we would expect lynx to be present.

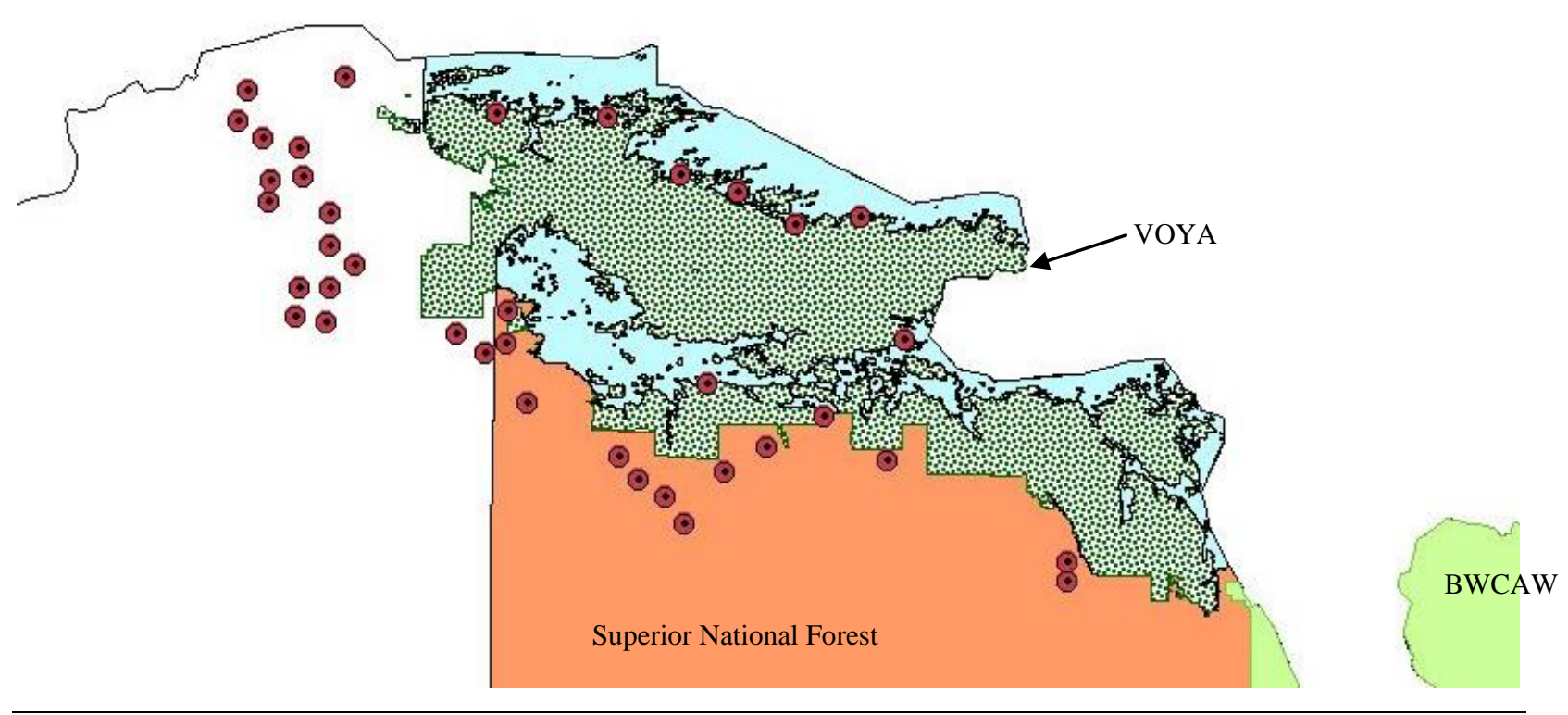

We used ten Silent Image Professional passive infrared trail cameras (Model PM35M13, Reconyx, LLP, Holmen, WI) with seven to eight cameras deployed concurrently from December 2007 through April 2008. We placed camera stations $\geq 1 \mathrm{~km}$ apart to reduce the chance that the same animal would visit more than one camera station (Erlinge, 1979; Soisalo \& Cavalcanti, 2006). Each camera was mounted approximately $1.5 \mathrm{~m}$ from the top of the snow at each station. We set cameras to be continuously active with no delay between trigger events. Cameras were usually deployed at a station for 12 to 14 days except on the last placement we kept cameras out for 30 or 44 days before retrieving them. At each station the leg of a road-killed white-tailed deer (Odocoileus virginianus) was placed about 4 meters from the camera and wired to a tree stem to keep the picture centered on the leg (Zielinski \& Kucera, 1995). 
Table 1. Cover type distribution (\% of total) from the LULC coverage in VOYA, within a $20 \mathrm{~km}$ buffer of VOYA, within the composite lynx home range donut, and within the core areas of lynx home ranges. Composite home range includes winter, summer, and annual areas (Burdett et al., 2007).

\begin{tabular}{|l|c|c|c|c|}
\hline LULC_name & VOYA & VOYA $+20 \mathrm{~km}$ & Lynx home range & $\begin{array}{c}\text { Lynx core } \\
\text { area }\end{array}$ \\
\hline Deciduous forest & 4 & 6 & 1 & 0 \\
\hline Grassland & 0 & 1 & 1 & 1 \\
\hline Mixedwood forest & 67 & 64 & 36 & 29 \\
\hline Marsh/Fen & 8 & 4 & 16 & 3 \\
\hline Bogs & 12 & 1 & 27 & 27 \\
\hline Coniferous forest & 1 & 4 & 2 & 5 \\
\hline Shrubby grassland & 1 & 8 & 11 & 20 \\
\hline $\begin{array}{l}\text { Regeneration/young } \\
\text { forests }\end{array}$ & 100 & 100 & 100 & 100 \\
\hline Sum & & & & \\
\hline
\end{tabular}

In addition to the deer leg, we also set out trapping lures that would attract felids, canids, and mustelids (Zielinski \& Kucera, 1995). We used Carman's Bobcat Gland Lure, Carman's Canine Call (Russ Carman, New Milford, Pa.), and Caven's Gusto (Minnesota Trapping Products, Pennock, MN). We placed lures $40-50 \mathrm{~cm}$ above the snow and $\geq 0.5 \mathrm{~m}$ apart about $3 \mathrm{~m}$ from the camera.

Cameras can take multiple pictures of an animal during a visit to a bait station. In some cases, lynx and mustelids have fed at a bait station for several minutes. We defined a visit as at least one photo of an individual of a species separated by photos of an individual of that same species by at least 5 minutes.

\section{Snow-track Searching}

Track surveys were conducted with a modification of the track survey protocol developed in Montana (Squires et al., 2004). The track survey was done by either snowmobile (on trails and unplowed roads) or vehicle (on plowed roads, when tracks are visible and distinct, before plowing or by searching snowbanks). Track surveys covered most of the roads and snowmobile trails in the vicinity of VOYA, although much of the Kabetogama peninsula was not surveyed because of limited trails and poor access (Fig. 4).

When possible we searched for lynx tracks within 24-72 hours of a snowfall. Snowfall rules were relaxed in some track surveys if field personnel felt that lynx tracks could be detected under existing snow conditions. Track logs were recorded with GPS units or reconstructed from field notes. 
Figure 4. Roads and trails used for the snow track survey routes in VOYA and adjacent lands.

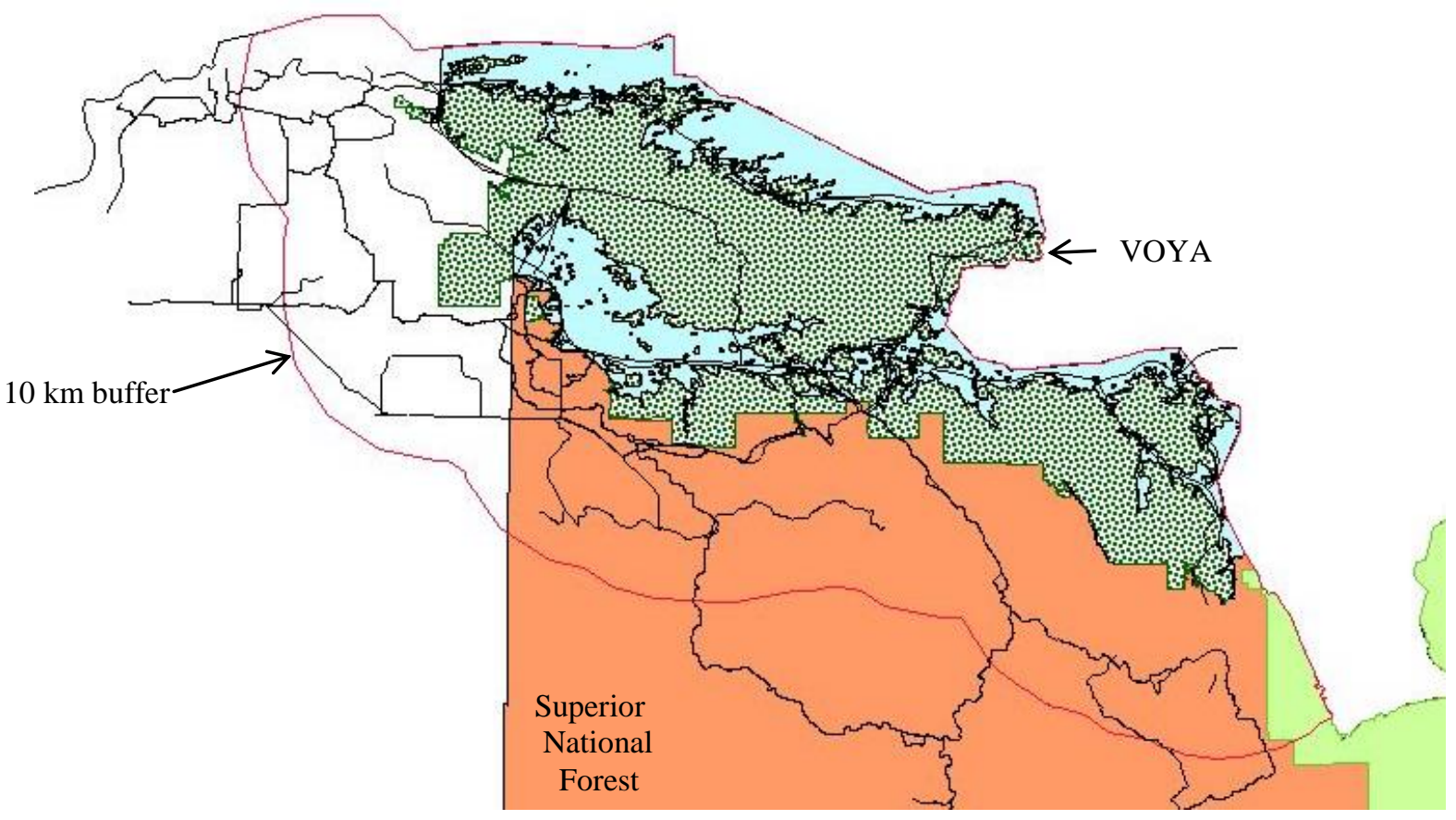

We also searched for tracks in the snow at remote camera stations along search transects and while walking in to the camera station on snowshoes (Hanson, 2009). Search transects included two nested triangles with the camera location as the central point. Transects were oriented with one side perpendicular to the shortest path from the access trail to the camera. The inner triangle was $100 \mathrm{~m}$ per side, the outer triangle $500 \mathrm{~m}$ per side, for a total transect distance of $1.8 \mathrm{~km}$ per station. The cameras were deployed off maintained snowmobile trails and roads, resulting in about $2.5 \mathrm{~km}$ of track searching while walking in to each camera station. UTM locations of all identifiable carnivore tracks were recorded into a handheld GPS. 


\section{Hare Pellet Survey}

The primary prey of Canada lynx throughout their range is snowshoe hare (Aubry et al., 2000). Most identifiable remains found in lynx scats from northeastern Minnesota were from snowshoe hare (Hanson \& Moen, 2008), except for white-tailed deer (Odocoileus virginianus) hair that was ingested because legs from road-killed deer were used as bait. Twenty-four of 26 kills found while snow-tracking were snowshoe hares; the remaining 2 kills included 1 ruffed grouse (Bonasa umbellus) and 1 spruce grouse (Dendragapus canadensis) (Burdett, 2007).

Snowshoe hare pellet density is highly correlated with snowshoe hare density in Minnesota (McCann 2006; McCann and Moen in prep) and therefore pellet counts provide an inexpensive index of lynx prey density. Plot size and geometry varies among investigators, but hare fecal pellet transects often consist of several plots placed at intervals with the transect being the sampling unit (McKelvey et al., 2002; Murray et al., 2002). These plots are usually permanently marked and then the same plot is counted each year. All fecal pellets within the plot boundary are counted and removed. Vegetation obscuring pellets is moved but pellets deeply incorporated into the organic layer of the forest floor are not counted. The transect is the sampling unit mainly to reduce the effect of local variation in pellet deposition.

We modified this protocol for hare pellet counts in Minnesota and began using plots that are not permanently marked (Moen et al., 2008b). We used $1 \mathrm{~m}^{2}$ circular plots placed at 20 to $25 \mathrm{~m}$ intervals as our transects. We counted hare pellets on 10 to 15 plots in a transect to evaluate local variance in pellet counts and determine the minimum number of plots per transect. For some transects we used straight lines, in other cases we used parallel lines separated by $20-25 \mathrm{~m}$ when 2 or 3 people were present. Because this is the first time that we have presented hare pellet counts based on uncleared plots, we include background material on developing this method in the Results section.

Pellet plot transects were placed randomly throughout the $10 \mathrm{~km}$ buffer strip and also along the perimeter of the Kabetogama peninsula (Fig. 5). Some pellet plots had been done since 2004 as part of the Superior National Forest lynx project. Plot locations were stratified so that plots were placed in each major cover type including the regenerating forest cover type that is an important part of lynx home ranges (Table 1). Plot locations were usually within $1 \mathrm{~km}$ of shoreline on the Kabetogama peninsula for access reasons. 
Figure 5. Hare pellet survey plots established in VOYA and the adjacent area that were sampled in $2007-2009$. At each point hare pellets in 5 to $151 \mathrm{~m}^{2}$ circular plots were counted along a transect. Points beyond the $10 \mathrm{~km}$ buffer were part of the Superior National Forest hare pellet counts. Plot locations in Ontario were only done in 2009.

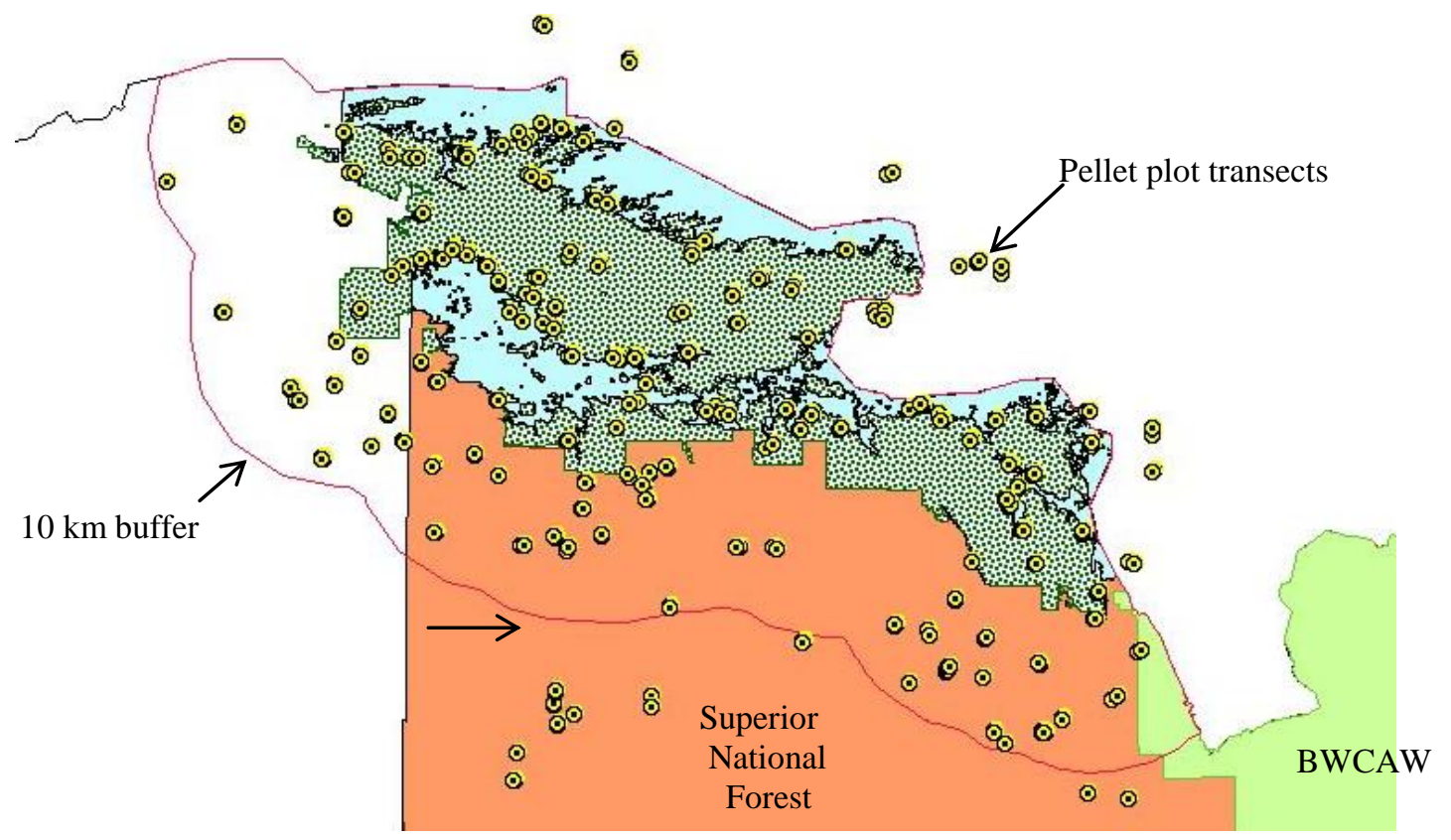

We compared pellet counts from transects in VOYA and the adjacent $10 \mathrm{~km}$ buffer to pellet counts within lynx home ranges from the telemetry study (Burdett et al., 2007). Pellet counts in the home ranges were divided into the core area of a home range, where about $60 \%$ of lynx telemetry locations were found, and from the outside of the core area to inside the 95\% kernel outline (Fig. 6). For the VOYA analysis we developed a composite core area and composite home range donut that included seasonal and annual home ranges from all radiocollared lynx. We assumed that the composite core area would represent habitat characteristics (e.g., cover type composition, hare pellet densities) that had been selected by lynx, while the composite home range donut and other points would represent habitat characteristics that were less preferred. Implicit in this assumption is that uncollared lynx were not present outside the composite home range area. Searches indicated that if lynx were present outside the composite home range they were present at low density (Moen et al., 2008).

Figure 6. The core area of a home range is the most intensively used portion. In the example to the right, the tan core area would have about $60 \%$ of lynx telemetry locations, and the green area represents the next $35 \%$ of telemetry locations in areas less intensively used. The "donut" is how we refer to the area outside of the core area and inside of the $95 \%$ kernel home range boundary.

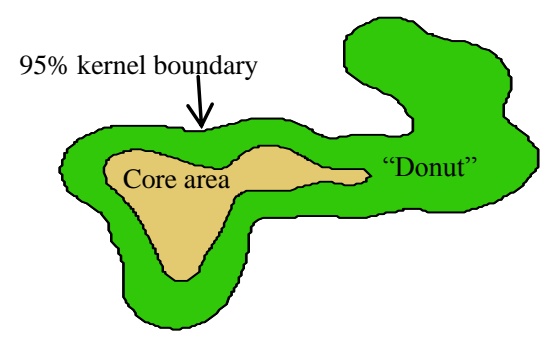




\section{Landscape Level Evaluation}

Data from hare pellet plots can be used to estimate snowshoe hare density for each cover type sampled. It is also possible to place hare pellet counts in a landscape context (McCann, 2006; Moen et al., 2008b). If measurements made in each cover type are representative of that cover type across a study area, pellet density can be extrapolated to a greater spatial extent using the LULC or GAP coverages. We identified areas of predicted higher quality hare habitat (McCann, 2006; McCann \& Moen, 2010) that also roughly correspond to area classified as better lynx denning habitat (Moen et al., 2008a).

We used hare pellet densities estimated in VOYA to predict hare pellet densities in areas that would approximate foraging bouts, daily foraging movements, and a typical core-area within a lynx home range in Minnesota (Burdett et al., 2007). We generated random points in ArcView 3.3, and then buffered these points to areas of $0.3,3.1$, and $25 \mathrm{~km}^{2}$ (radii of about $300 \mathrm{~m}, 1 \mathrm{~km}$, and $2.8 \mathrm{~km}$, respectively). We eliminated points with buffered areas that were $>25 \%$ outside of the appropriate boundary, and also eliminated all buffer areas that were $>25 \%$ open water. These spatial estimates of pellet density that incorporated landscape composition were compared to pellet density within and adjacent to lynx home ranges in the Superior National Forest radiotelemetry project.

Figure 7. Example of random points in VOYA, the $10 \mathrm{~km}$ buffer strip, and the $20 \mathrm{~km}$ buffer strip used to predict hare density. Points were surrounded with a circular buffer resulting in areas of $0.3,3.1$, and $25 \mathrm{~km}^{2}$. Different sets of random points were used for $0.3,3.1$, and $25 \mathrm{~km}^{2}$ circles.

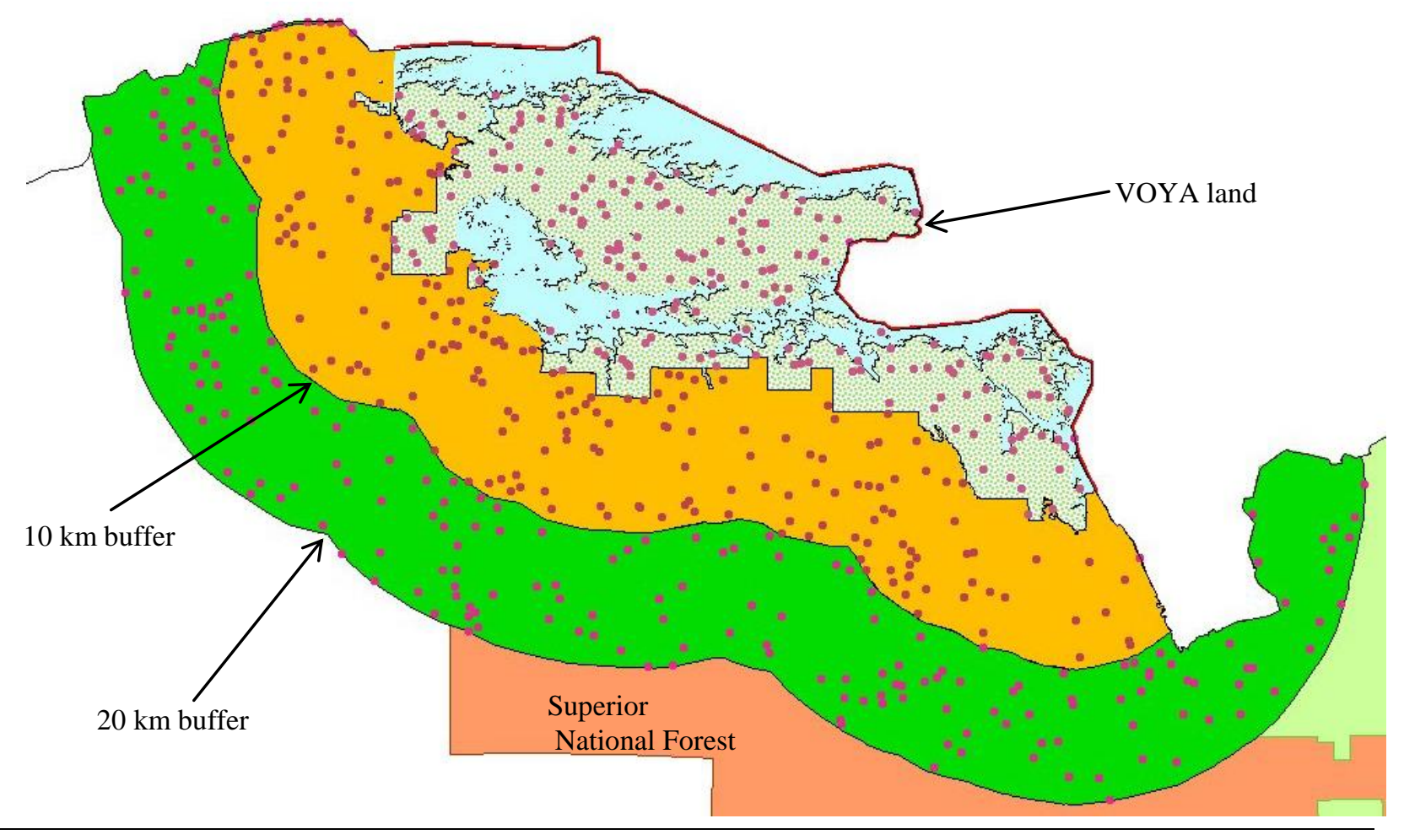


We also compared the predicted hare density in and near VOYA to predicted hare density from areas within and near lynx home ranges from the SNF radiotelemetry project (Burdett et al., 2007). This comparison is based on the assumption that prey density would be higher within lynx home ranges than in adjacent areas where lynx were rarely present based on snow-track observations (Moen et al., 2008b). In addition, prey density would be higher within the core-area of a lynx home range than in the area outside of the core area (Fig. 8). We compared predicted hare densities in VOYA to predicted hare densities within lynx home ranges in northeastern Minnesota.

Finally, we compared denning habitat at VOYA to denning habitat in lynx areas, and we placed VOYA in the spatial context of a male and female lynx home range from the telemetry study (Burdett et $a l ., 2007)$. The intent of this analysis was to determine how many lynx might be resident on VOYA and the surrounding area at a single time, if habitat conditions were similar to conditions in the radiotelemetry project. Home ranges in southern lynx populations are about $75 \mathrm{~km}^{2}$ for females and $150 \mathrm{~km}^{2}$ for males. This corresponds to circles with radii of about 4 and $7 \mathrm{~km}$, respectively.

Figure 8 . The $10 \mathrm{~km}$ and $20 \mathrm{~km}$ buffer strips around VOYA and the composite lynx home ranges. We predicted hare density in each buffer strip around the composite 95\% home ranges of radiocollared lynx (Burdett et al., 2007), and in buffer strips around VOYA needed to predict hare density.

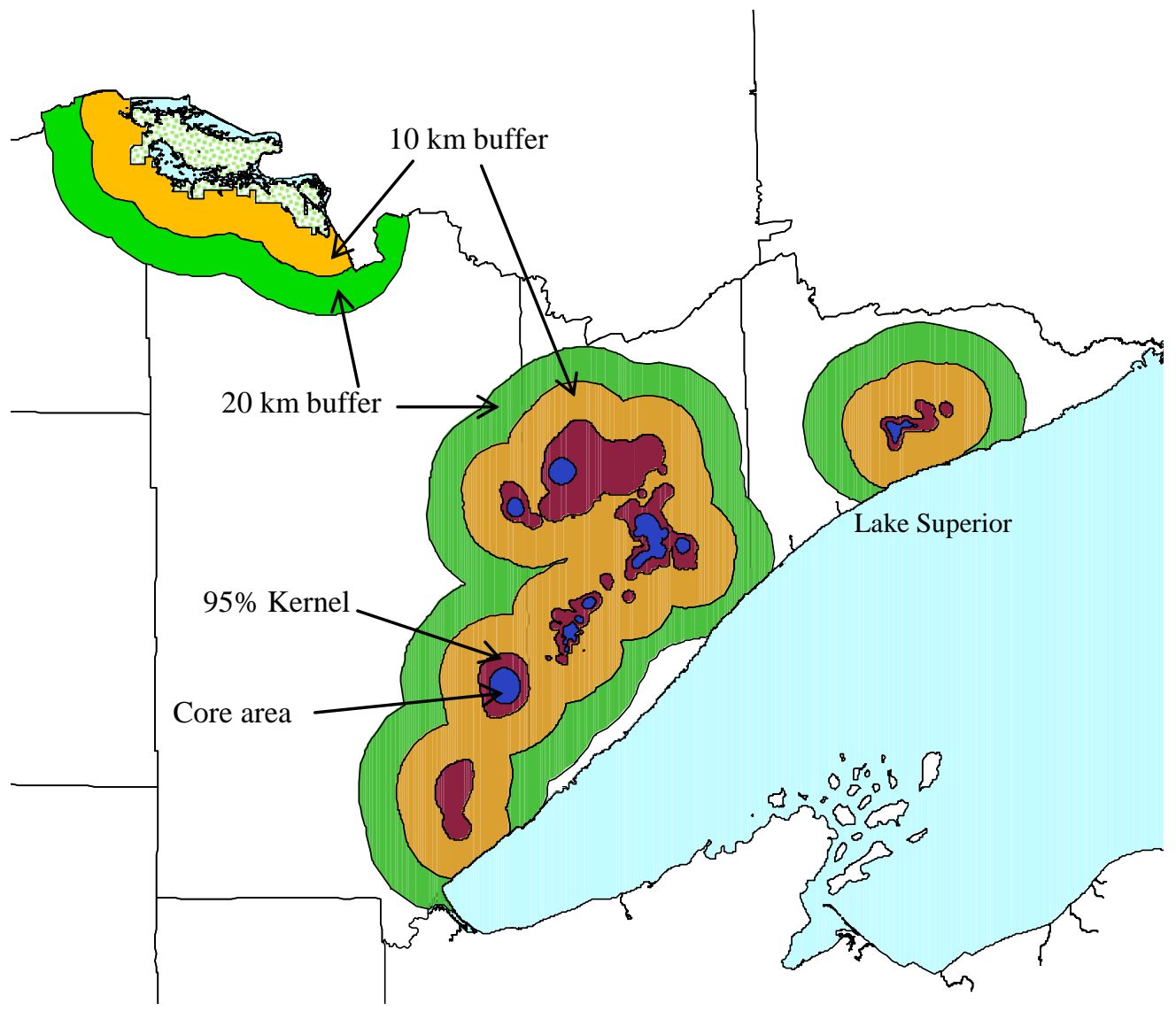




\section{Results}

We found no evidence supporting the presence of resident lynx in VOYA using remote cameras and track searches (Fig. 9). The lack of resident lynx is consistent with searches for lynx presence from 2000 to 2004 (Route et al., 2009). No lynx were seen in pictures taken at camera stations during the 2008 winter. This does not mean that lynx are never present in VOYA, however. The picture of a lynx on the cover of this report was taken with a trail camera at a bait station in 2009. The hare pellet data provided a clue as to why lynx do not appear to be resident in VOYA and the surrounding area at the present time. Pellet densities in and near VOYA were $50 \%$ to $67 \%$ of pellet densities in core areas of lynx home ranges in the Superior National Forest telemetry project.

Figure 9. Locations of snow-tracking by snowmobile or by truck, locations of camera stations, and locations of hare pellet plot transects in VOYA and the adjacent area. Hare pellet plots in Ontario were done in 2009. The number of carnivore species seen at a camera site is coded in the symbol. The snow-tracking tracks (snowmobile or car) are shown as a solid black line.

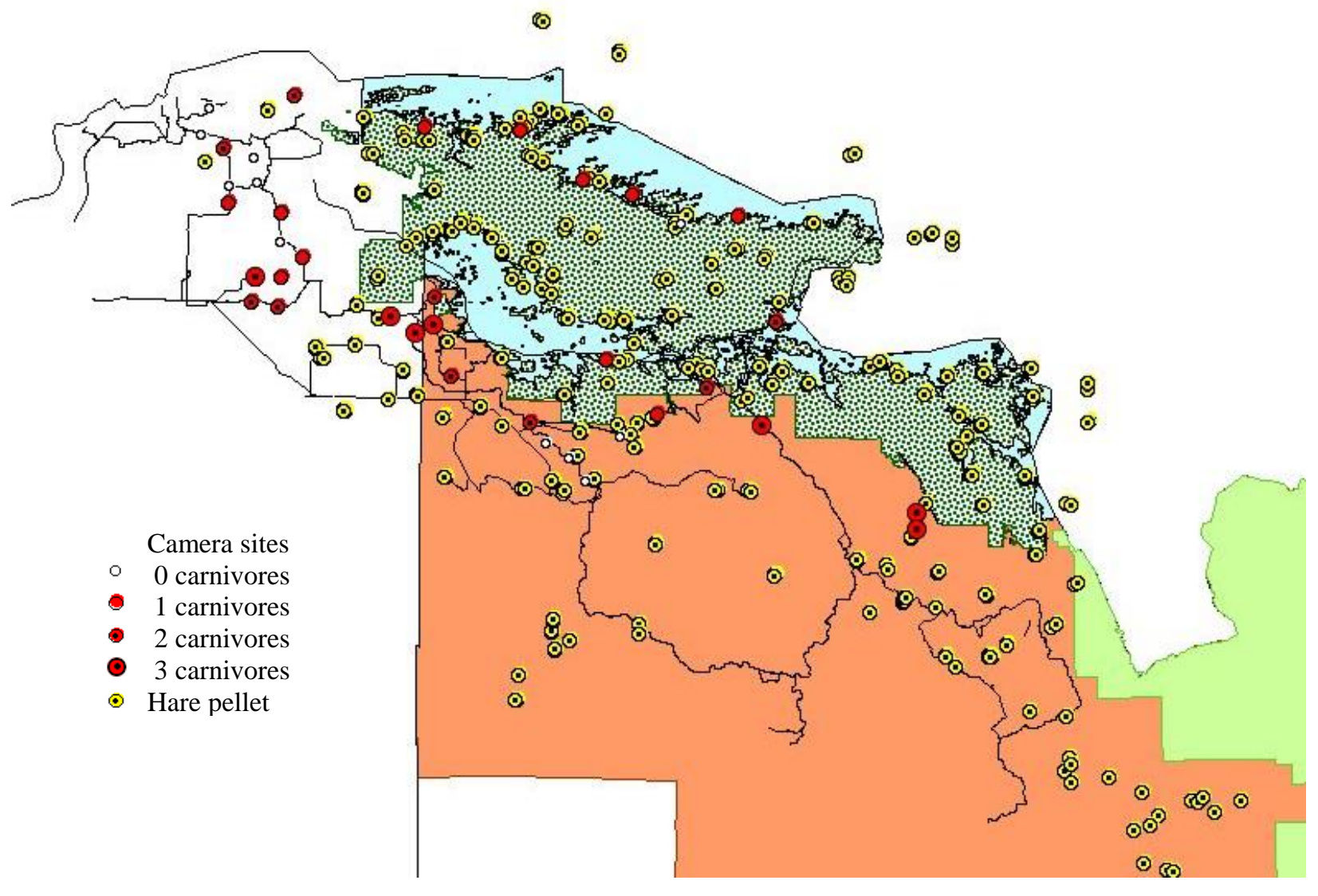




\section{Using Remote Cameras ${ }^{1}$}

We deployed remote cameras at 39 locations (Figs. 3, 9) for 748 camera-days in 2007-2008. The cameras recorded 1,057 visits by animals (e.g., the cover picture), but none of these visits were by lynx. A visit was the time an animal was present at the camera station without leaving. Multiple pictures could be taken in a single visit. Carnivores recorded in the cameras were American marten (Martes americana), fisher (M. pennanti), ermine (Mustela erminea), red fox (Vulpes vulpes), coyote (Canis latrans), domestic $\operatorname{dog}($ C. familiaris), and gray wolf (C. lupus). Other mammals in pictures included deer (Odocoileus virginianus), snowshoe hare (Lepus americanus), and red squirrel (Tamiasciurus hudsonicus). There was variation among camera stations, but about 25 to 30 visits were recorded on a camera over 14,30 , or 44 days with 16 visits by carnivores on each camera deployment (Table 2). Some cameras recorded no visits by animals the entire time they were deployed (Fig. 9) even though nearby cameras recorded carnivore visits. On the last camera deployment, either 30 or 44 days, 3 of 10 cameras had no animals recorded at the bait during the entire period.

Table 2. Summary statistics for remote camera deployments.

\begin{tabular}{|l|c|c|}
\hline & Mean \pm SD & Range \\
\hline Days deployed & $19.18 \pm 11.21$ & $12-44$ \\
\hline Total visits & $27.10 \pm 30.17$ & $0-119$ \\
\hline Total species & $2.82 \pm 2.51$ & $0-9$ \\
\hline Carnivore visits & $15.90 \pm 17.21$ & $0-60$ \\
\hline Carnivore species & $1.28 \pm 1.10$ & $0-3$ \\
\hline
\end{tabular}

Regenerating Forest had the fewest number of carnivore visits (7 per deployment), but was only significantly different from the Mixed Forest cover type which had the most carnivore visits at 24 per deployment $(\mathrm{K}-\mathrm{W}$ statistic $=9.6, P=0.048)$. Deciduous, Bog, and Coniferous cover types were intermediate and not different from either the Mixed Forest or the Regenerating Forest cover type. When scaled to the number of carnivore visits per day, there were no differences among cover types (K-W statistic $=9.7, P=0.083)$. Whether cameras were inside or outside VOYA did not affect total carnivore visits $(\mathrm{K}-\mathrm{W}$ statistic $=2.2, P=0.14)$ or carnivore visits per day $(\mathrm{K}-\mathrm{W}$ statistic $=2.2, P=0.14)$. Being inside or outside of VOYA also did not affect the number of carnivore species visiting a camera station $(\mathrm{K}-\mathrm{W}$ statistic $=0.01, P=0.90)$. The rank order for the number of carnivore species visiting a camera station among cover types was lowest for the Regenerating Forest cover type.

\footnotetext{
${ }^{1}$ Remote camera data is analyzed further in Hansen (2009)
} 


\section{Searching for Lynx Tracks}

We searched about 1,080 km of trails and roads for lynx tracks from December 2006 to March 2007, and about $280 \mathrm{~km}$ from December 2007 to March 2008. We also searched for tracks on about 90 $\mathrm{km}$ of transects associated with the camera stations while on snowshoes. We did not identify any tracks that could be positively identified as lynx. This is consistent with search effort from 2000 to 2004: over $60 \mathrm{~km}$ of snowshoe transects were followed with 1 set of tracks identified as possibly from lynx (Route et al., 2009). Additional searches between transects from 2000 to 2004 added more $\mathrm{km}$ to that search effort but distance was not documented, thus the $60 \mathrm{~km}$ estimate is a minimum (Route et al., 2009).

Lynx tracks were not detected around camera stations, but other carnivore tracks were observed. We found tracks of American marten, fisher, ermine, red fox, medium-sized canid (coyote or dog), and gray wolf. In the $1.8 \mathrm{~km}$ walked as transects around each of 29 camera stations (52 km total), and the approximately $39 \mathrm{~km}$ walking into camera stations to deploy and to remove cameras, no lynx tracks were detected, although tracks of each of the above species were identified (Table 3). Domestic dog tracks could not be differentiated from coyote tracks, but other species were identified from tracks. There were no differences among cover types in total carnivore tracks observed $(\mathrm{K}-\mathrm{W}$ statistic $=4.8, P=0.31)$ or in tracks per day since the last snowfall $(\mathrm{K}-\mathrm{W}$ statistic $=1.3, P=0.86)$. Similarly, there were no differences inside or outside the park in total carnivore tracks observed $(\mathrm{K}-\mathrm{W}$ statistic $=1.8, P=0.18)$ or in tracks per day since the last snowfall $(\mathrm{K}-\mathrm{W}$ statistic $=1.4, P=0.23)$.

Table 3. Summary statistics for carnivore tracks per day since last snowfall detected in snow around camera stations in each cover type.

\begin{tabular}{|l|c|c|}
\hline & Mean \pm SD & Range \\
\hline Coniferous Forest & $2.93 \pm 2.93$ & $1-5$ \\
\hline Regenerating Forest & $3.64 \pm 3.81$ & $1-8$ \\
\hline Bog & $4.00 \pm 4.00$ & $2-10$ \\
\hline Deciduous Forest & $1.95 \pm 1.75$ & $0-5$ \\
\hline Mixed Forest & $4.01 \pm 6.02$ & $0-21$ \\
\hline
\end{tabular}




\section{Prey Species and Hare Pellet Plots}

Non-permanent plots can be used to count hare pellets in Minnesota because there are few pellets from the previous year on uncleared pellet plots relative to previously cleared pellet plots (Moen et al., 2008b). We first evaluate two questions on hare pellet sampling using non-permanent plots: (1) Is there a 1:1 relationship between pellet counts on cleared and uncleared plots at the transect (sampling unit) level when there are 10 plots per transect, and (2) How does the relationship between mean pellet count and actual (true) pellet count change as the number of plots per transect increases.

The number of pellets counted is lower in uncleared pellet plots than in cleared plots at high pellet densities (Fig. 10). The slope approaches 1 and the y-intercept remains not different from 0 if plots with high pellet counts are removed (Table 4). The relationship up to 15 pellets per $\mathrm{m}^{2}$ is $1: 1$. If there were many of the previous year's pellets present, then we would expect there to be more pellets in the uncleared plot than in the cleared plot across all pellet densities and the slope to be $>1$. Fewer than expected pellets in the uncleared plots at high pellet densities could be due to local variation in pellet deposition. Another reason pellet counts or uncleared plots could be lower is that there is a higher chance of missing pellets at the higher pellet counts when litter has not been cleared in the past. Pellets could be hidden in the litter, or could be swept out by mistake as litter is moved from the plot. It is possible but less likely that snowshoe hare would be more likely to deposit pellets in a cleared pellet plot.

Figure 10. Contrasting measurement of cleared and uncleared plots. Pellets from a simulated transect of 10 cleared plots compared to pellets removed from adjacent (within $3 \mathrm{~m}$ ) uncleared plots. The regression line is based on all transects with cleared and uncleared plots.

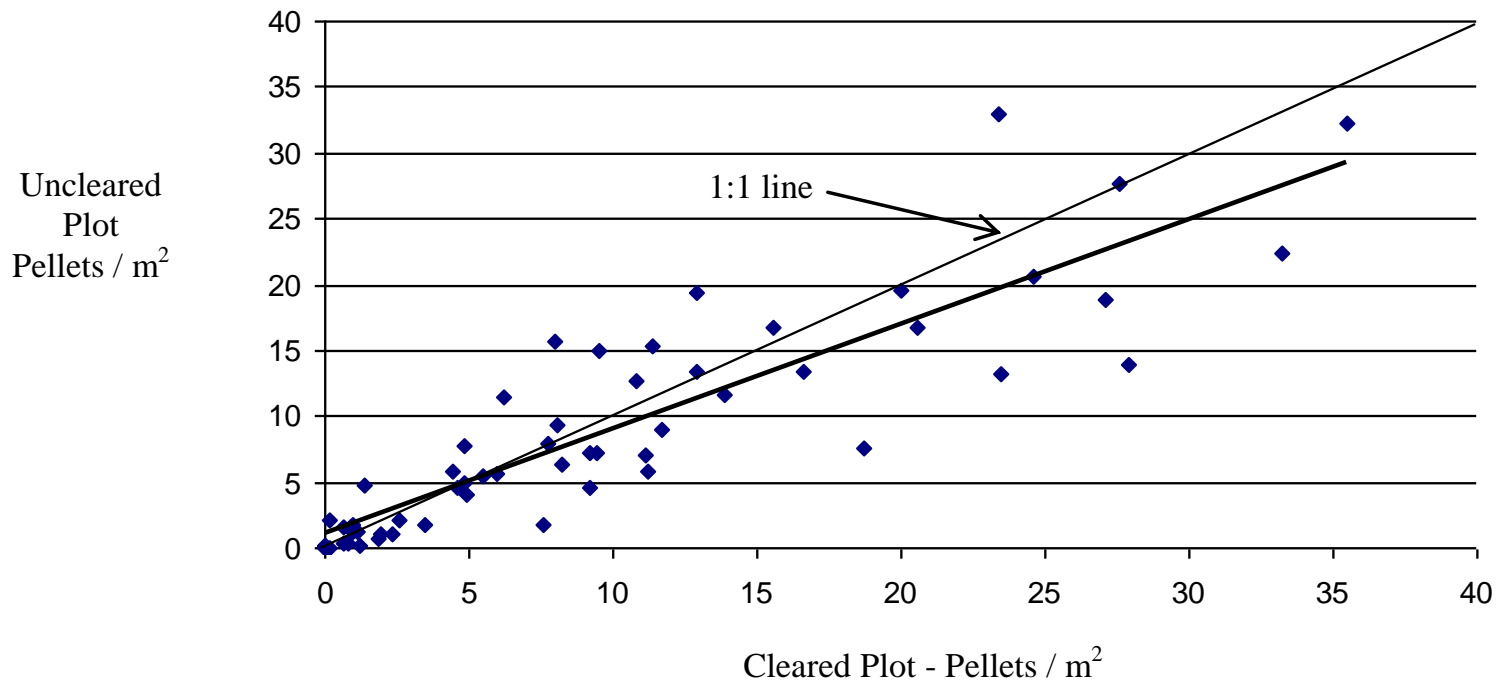


Table 4. Regression parameters for comparison of pellet counts in cleared and uncleared plots. Maximum Use indicates the maximum number of pellets in cleared plots that was used for the comparison. If counts were higher than the maximum they were set to Maximum Use. Regression statistics are from linear regression. The slope becomes not significantly different from 1 as Maximum Use is decreased, and the y-intercept is not different from 0.

\begin{tabular}{|c|c|c|c|c|c|c|c|}
\hline Maximum Use & Slope & $t$-value & $P$ & Constant & $t$-value & $P$ & $r^{2}$ \\
\hline All & $0.80 \pm 0.05$ & 15.18 & 0.00 & $0.98 \pm 0.68$ & 1.45 & 0.15 & 0.80 \\
\hline 25 & $0.87 \pm 0.08$ & 11.41 & 0.00 & $0.61 \pm 0.61$ & 0.99 & 0.32 & 0.72 \\
\hline 20 & $0.88 \pm 0.07$ & 12.92 & 0.00 & $0.58 \pm 0.67$ & 0.86 & 0.40 & 0.76 \\
\hline 15 & $0.98 \pm 0.09$ & 10.98 & 0.00 & $0.23 \pm 0.59$ & 0.39 & 0.70 & 0.72 \\
\hline
\end{tabular}

The second question is how many plots should be done in a transect. On the permanent plot network used earlier in the Superior National Forest, we used 5 plots per transect (Moen et al., 2008b). As the number of plots in a transect increases, the scatter of points approaches the 1:1 line as the true mean for $\mathrm{n}=15$ plots is reached (Fig. 11).

Figure 11. Effect of number of plots on mean pellet counts, contrasting when $n=15$ plots against 1 (filled diamond), 5 (open symbol), and 10 (yellow symbols) plots in a transect. Between 5 and 10 plots in a transect smoothing out from fine-scale variation occurs and the slope approaches 1 with $r^{2}>0.7$.

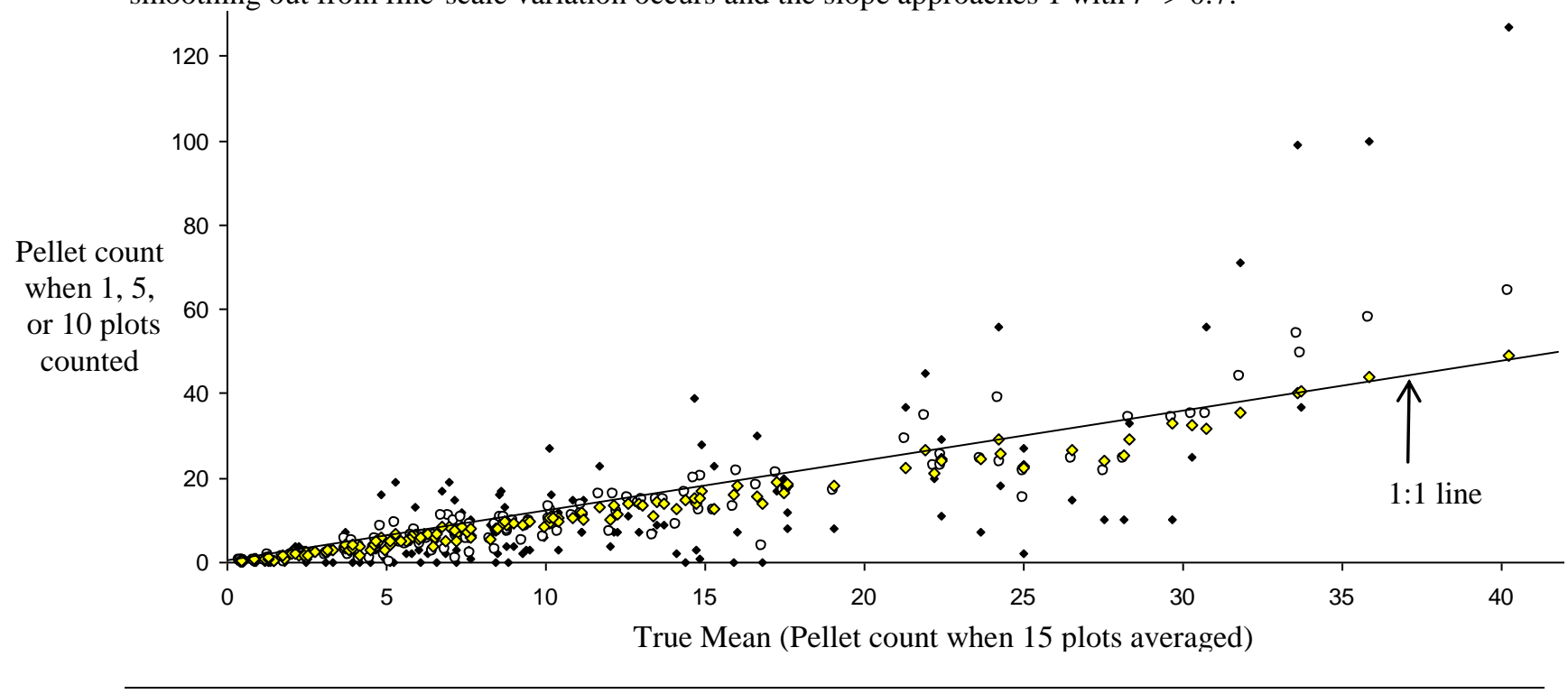

In the spring of 2007 we counted pellets on 120 plots in and near VOYA spread across representative cover types (Table 5). An additional 28 plots were counted in the spring of 2008, and 150 additional plots were counted under other funding in the spring of 2009. Generally, hare pellet density in VOYA was much lower than hare pellet density in areas where lynx are present in Minnesota (Moen et al., 2008b). 
Table 5. Hare pellet density (mean pellets $/ \mathrm{m}^{2}$ ) in LULC cover types in VOYA and the adjacent area in 2007-2009. Pellet density was calculated based on all transects within a cover type each year using the mean of 5-10 plots per transect.

\begin{tabular}{|l|c|c|c|c|c|c|}
\hline \multicolumn{1}{|c|}{ Winter: } & \multicolumn{2}{c|}{ 2006 - 2007 } & \multicolumn{2}{c|}{ 2007 - 2008 } & \multicolumn{2}{c|}{ 2008 - 2009 } \\
\hline Cover Type & $\mathbf{n}$ & Mean \pm SD & n & Mean \pm SD & n & Mean \pm SD \\
\hline Deciduous forest & 15 & $0.31 \pm 0.88$ & 5 & $0.10 \pm 0.15$ & 10 & $2.00 \pm 5.501$ \\
\hline Open water & 8 & $0.06 \pm 0.18$ & 5 & $0.00 \pm 0.00$ & 2 & $0.00 \pm 0.00$ \\
\hline Grassland & 5 & $0.44 \pm 0.99$ & & & 1 & 0.00 \\
\hline Mixedwood forest & 58 & $0.83 \pm 1.71$ & 16 & $0.76 \pm 1.65$ & 82 & $0.18 \pm 0.83$ \\
\hline Marsh/Fen & 10 & $0.14 \pm 0.33$ & 2 & $0.00 \pm 0.00$ & 2 & $0.00 \pm 0.00$ \\
\hline Bogs & 10 & $0.22 \pm 0.39$ & & & 5 & $0.06 \pm 0.13$ \\
\hline Coniferous forest & 2 & $0.09 \pm 0.12$ & & & 3 & $0.00 \pm 0.00$ \\
\hline Regeneration/Young Forests & 12 & $0.50 \pm 0.91$ & & & 2 & $0.20 \pm 0.14$ \\
\hline Ontario & & & & & 12 & $0.38 \pm 1.03$ \\
\hline
\end{tabular}

${ }^{1}$ In 2008-2009 1 of 10 transects in deciduous forest had 18 pellets, mean \pm SD of other 9 plots was $0.27 \pm 0.50$

It is possible to estimate overall hare pellet density across the landscape by using the cover type composition and the estimated hare pellet density (Table 5). The predicted hare pellet density in VOYA and in the $20 \mathrm{~km}$ buffer outside of the VOYA boundary was about 0.6 pellets $/ \mathrm{m}^{2}$ (Table 6), even when the single high pellet count from Deciduous forest cover type was included.

Table 6. Cover type composition and weighted mean hare pellet density in LULC cover types in VOYA and adjacent area (based on 2007-2008 pellet data). Areas of open water were eliminated from these calculations. Pellet density was calculated based on all transects within a cover type applied to proportional area, resulting in an overall estimate of about 0.6 pellets $/ \mathrm{m}^{2}$.

\begin{tabular}{|l|c|c|c|c|}
\hline Cover Type & $\begin{array}{c}\text { VOYA } \\
\text { (\% of landscape) }\end{array}$ & $\begin{array}{c}20 \mathrm{~km} \text { buffer } \\
\text { (\% of landscape) }\end{array}$ & $\begin{array}{c}\text { VOYA } \\
\text { Pellet density }\end{array}$ & $\begin{array}{c}20 \mathrm{~km} \text { buffer } \\
\text { Pellet density }\end{array}$ \\
\hline Deciduous forest & 4 & 7 & 0.01 & 0.02 \\
\hline Mixedwood forest & 67 & 63 & 0.55 & 0.52 \\
\hline Marsh/fen & 8 & 3 & 0.01 & 0.00 \\
\hline Bogs & 12 & 12 & 0.03 & 0.02 \\
\hline Coniferous forest & 1 & 1 & 0.00 & 0.00 \\
\hline Shrubby grassland & 7 & 3 & 0.00 & 0.00 \\
\hline Regenerating forest & 1 & 10 & 0.00 & 0.05 \\
\hline Total & 100 & 98 & & 0.62 \\
\hline Pellet density & & & 0.61 & \\
\hline
\end{tabular}




\section{Landscape Scale Analysis of Prey Density}

We used ArcView to create spatial areas for analysis of snowshoe hare density at the landscape scale. For VOYA we used the area of the entire park, and buffer strips that were $0-10 \mathrm{~km}$ and $10-20$ $\mathrm{km}$ from the park boundary (Fig. 12). GIS analysis was limited to the U.S. because we did not have comparable satellite imagery for Ontario. We included the buffer strips in the analysis to assess if areas adjacent to VOYA also contained suitable lynx habitat. We used a similar scheme to define lynx use areas, with GIS sampling within the core area, within the home range, and in buffer strips equivalent to the buffer strips around VOYA (Fig. 12). Pellet counts in each cover type in VOYA and the surrounding area were based on pellet counts in 2007 and 2008 within the $20 \mathrm{~km}$ buffer (Fig. 11). Pellet counts in each cover type for the area used by radiocollared lynx were from 2004 to 2008 (Moen et al., 2008b).

Figure 12. The 10 and $20 \mathrm{~km}$ buffer strips around VOYA and the composite lynx home ranges with $25 \mathrm{~km}^{2}$ randomly placed circular areas corresponding to a lynx core area in the $10 \mathrm{~km}$ buffer strip around the composite home range.

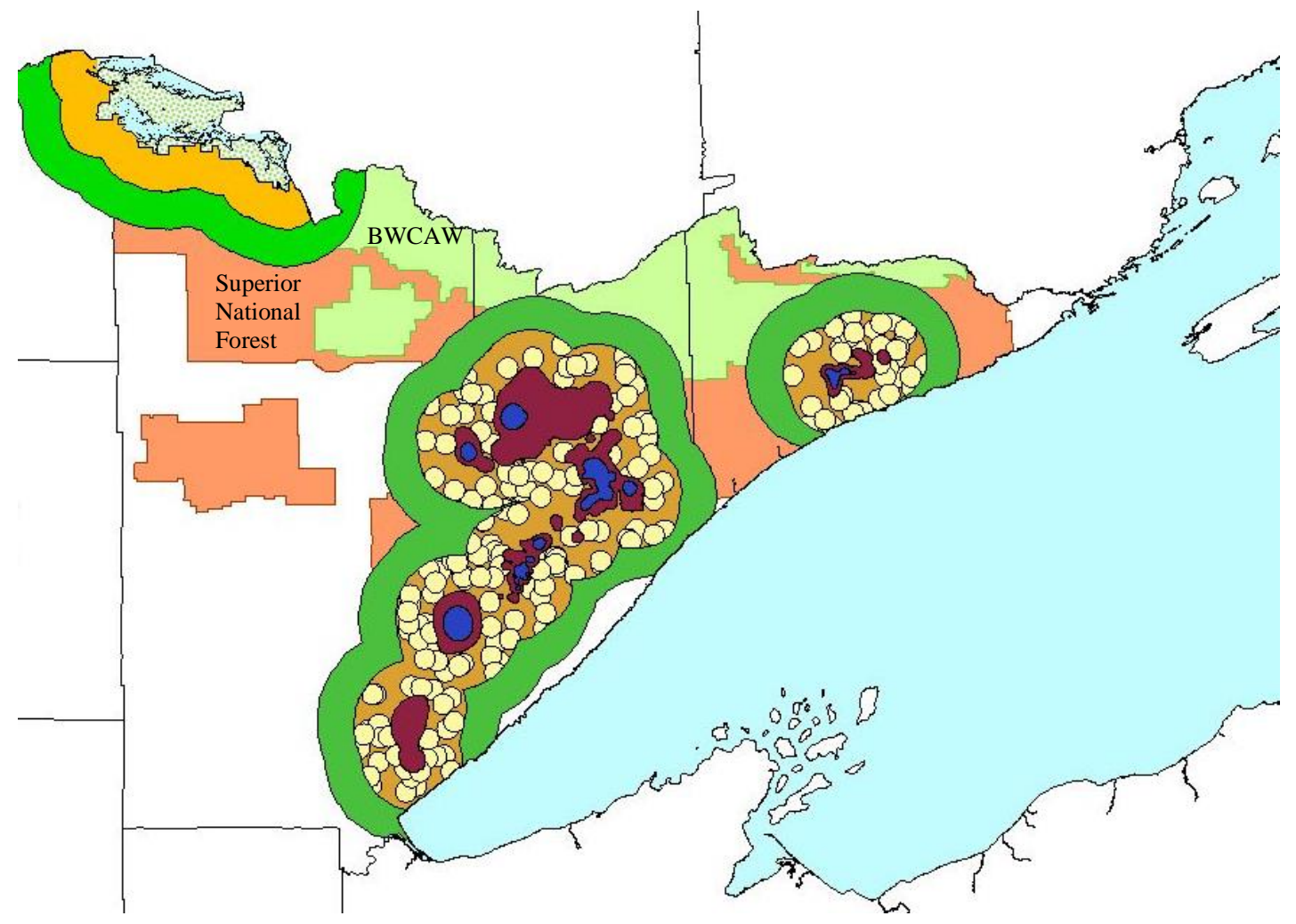


We calculated weighted mean snowshoe hare pellet densities for random locations within each sample area in VOYA and within the areas used by radiocollared lynx. Calculations for VOYA and for the radiocollared lynx area were done similarly. Random locations were $0.3 \mathrm{~km}^{2}$ circles corresponding to an individual lynx activity bout, $3.1 \mathrm{~km}^{2}$ circles corresponding to a lynx's daily foraging radius, and 25 $\mathrm{km}^{2}$ circles corresponding to the core area in a lynx home range. Snowshoe hare pellet density (and snowshoe hare density) was about 1.5 to 2 times higher within the lynx areas than in VOYA (Table 7). Predicted pellet densities were higher within VOYA than in either the 10 or $20 \mathrm{~km}$ buffer around VOYA, and pellet densities at VOYA were lower than in lynx home ranges $\left(\mathrm{F}_{4,2325}=371, \mathrm{P}<0.001\right)$.

Differences in predicted pellet density were similar for $3.1 \mathrm{~km}^{2}$ and $25 \mathrm{~km}^{2}$ circles. Pellet density was highest in the lynx core area, next highest in the 95\% kernel, and lowest in VOYA $\left(3.1 \mathrm{~km}^{2}\right.$ circles: $\mathrm{F}_{4,1560}=686, \mathrm{P}<0.001,25 \mathrm{~km}^{2}$ circles: $\left.\mathrm{F}_{5,750}=295, \mathrm{P}<0.001\right)$. The $10 \mathrm{~km}$ and $20 \mathrm{~km}$ buffer strips around the composite lynx home range also had higher pellet density than the VOYA area (Table 7).

Table 7. Predicted pellet density (pellets $/ \mathrm{m}^{2}$ ) in $0.3 \mathrm{~km}^{2}, 3.1 \mathrm{~km}^{2}$, and $25 \mathrm{~km}^{2}$ circles in the core area, in the $95 \%$ kernel (excluding core area), in VOYA, and in 10 and $20 \mathrm{~km}$ donuts around VOYA.

\begin{tabular}{|l|c|c|}
\hline & \multicolumn{2}{|c|}{ Pellet density } \\
\hline & Mean \pm SD & Range \\
\hline 0.3 km circles & & $0.27-2.00$ \\
\hline Core area & $1.09 \pm 0.42$ & $0.10-2.00$ \\
\hline $95 \%$ Kernel & $0.95 \pm 0.36$ & $0.00-0.83$ \\
\hline VOYA & $0.60 \pm 0.25$ & $0.00-0.83$ \\
\hline VOYA 10 km donut & $0.49 \pm 0.23$ & $0.00-0.83$ \\
\hline VOYA 20 km donut & $0.51 \pm 0.23$ & \\
\hline 3.1 km ${ }^{2}$ circles & & $0.86-1.55$ \\
\hline Core area & $1.14 \pm 0.13$ & $0.87-1.30$ \\
\hline $95 \%$ Kernel & $0.93 \pm 0.01$ & $0.33-0.74$ \\
\hline VOYA & $0.59 \pm 0.01$ & $0.25-0.67$ \\
\hline VOYA 10 km donut & $0.49 \pm 0.01$ & $0.26-0.72$ \\
\hline VOYA 20 km donut & $0.52 \pm 0.01$ & $0.72-1.21$ \\
\hline $\mathbf{2 5}$ km circles & & $0.42-1.34$ \\
\hline Inside home range & $1.00 \pm 0.11$ & $0.27-1.33$ \\
\hline Home range 10K donut & $0.89 \pm 0.17$ & $0.25-0.74$ \\
\hline Home range 20K donut & $0.80 \pm 0.19$ & $0.27-0.69$ \\
\hline VOYA & $0.58 \pm 0.10$ & $0.26-0.73$ \\
\hline VOYA 10 km donut & $0.51 \pm 0.11$ & \\
\hline VOYA 20 km donut & $0.50 \pm 0.13$ & \\
\hline
\end{tabular}


Cover type composition changes slightly as the sampling area increases. At the sample area corresponding to a foraging bout $\left(0.3 \mathrm{~km}^{2}\right)$, the circles could fall completely within a cover type, and there was a broad range in minimum and maximum pellet densities (Table 7). As sampling area increased to daily use area $\left(3.1 \mathrm{~km}^{2}\right)$ and approximating a female home range $\left(25 \mathrm{~km}^{2}\right)$, ranges in pellet densities were less extreme because multiple cover types were included in a mean pellet density (Tables 7, 8, 9). Differences between the Regenerating Forest cover type areas in the core area (Table 8 ) and the home range (Table 9) indicate the degree to which lynx are selecting regenerating forests in the telemetry project study area..

Table 8. Differences in cover type composition $(\% \pm \mathrm{SD})$ in $3.1 \mathrm{~km}^{2}$ circles in the lynx core area, in the $95 \%$ kernel area, in VOYA, and in 10 and $20 \mathrm{~km}$ donuts around VOYA. Bolded cover types have higher snowshoe hare densities and have higher percent coverage in the core areas of home ranges.

\begin{tabular}{|l|c|c|c|c|c|}
\hline & Core Area & $95 \%$ Kernel & VOYA & $10 \mathrm{~km}$ Buffer & $20 \mathrm{~km}$ Buffer \\
\hline Wetland Bogs & $15 \pm 13$ & $17 \pm 15$ & $13 \pm 13$ & $17 \pm 21$ & $13 \pm 18$ \\
\hline Conifer forest & $28 \pm 17$ & $27 \pm 22$ & $1 \pm 2$ & $3 \pm 6$ & $3 \pm 5$ \\
\hline Deciduous forest & $0 \pm 0$ & $1 \pm 4$ & $3 \pm 7$ & $12 \pm 16$ & $11 \pm 15$ \\
\hline Grassland & $1 \pm 3$ & $1 \pm 4$ & $0 \pm 0$ & $3 \pm 8$ & $5 \pm 13$ \\
\hline Wetland Fens & $2 \pm 2$ & $5 \pm 4$ & $8 \pm 8$ & $4 \pm 5$ & $3 \pm 3$ \\
\hline Mixedwood forest & $26 \pm 17$ & $35 \pm 20$ & $65 \pm 19$ & $38 \pm 23$ & $40 \pm 26$ \\
\hline Regenerating forest & $22 \pm 14$ & $9 \pm 10$ & $1 \pm 5$ & $16 \pm 16$ & $19 \pm 18$ \\
\hline Shrubby Grassland & $5 \pm 10$ & $3 \pm 8$ & $8 \pm 14$ & $6 \pm 9$ & $4 \pm 5$ \\
\hline Total & 99 & 98 & 99 & 99 & 98 \\
\hline
\end{tabular}

Regenerating Forest has the highest hare density among cover types and covers over $20 \%$ of a typical lynx core area (Table 8). Conifer forest is the other cover type with higher snowshoe hare density, and also covers a higher proportion of lynx home ranges (Table 9). Relatively little of the VOYA forest was classified as conifer in the LULC, and pellet density in the Conifer cover type in VOYA was low (Table 5). 
Table 9. Differences in cover type composition ( $\% \pm \mathrm{SD}$ ) in $25 \mathrm{~km}^{2}$ circles inside the home range (including core area and 95\% kernel home range) in VOYA, and in 10 and $20 \mathrm{~km}$ donuts around VOYA. Bolded cover types have higher snowshoe hare densities and cover more of the core area of home ranges.

\begin{tabular}{|l|c|c|c|c|c|}
\hline & Lynx HR & 10K from HR & VOYA & 10 K buffer & 20K buffer \\
\hline Wetland Bogs & $15 \pm 9$ & $16 \pm 15$ & $13 \pm 7$ & $20 \pm 18$ & $15 \pm 10$ \\
\hline Conifer Forest & $31 \pm 17$ & $17 \pm 18$ & $1 \pm 1$ & $2 \pm 3$ & $3 \pm 3$ \\
\hline Deciduous Forest & $1 \pm 1$ & $5 \pm 7$ & $2 \pm 2$ & $9 \pm 9$ & $13 \pm 12$ \\
\hline Grassland & $1 \pm 2$ & $1 \pm 4$ & $0 \pm 0$ & $1 \pm 4$ & $3 \pm 8$ \\
\hline Wetland Fens & $4 \pm 2$ & $3 \pm 2$ & $8 \pm 6$ & $6 \pm 5$ & $3 \pm 2$ \\
\hline Mixedwood Forest & $33 \pm 14$ & $42 \pm 17$ & $65 \pm 13$ & $39 \pm 19$ & $36 \pm 19$ \\
\hline Regenerating Forest & $12 \pm 9$ & $10 \pm 8$ & $0 \pm 1$ & $16 \pm 12$ & $22 \pm 13$ \\
\hline Shrubby Grassland & $3 \pm 6$ & $5 \pm 10$ & $11 \pm 14$ & $6 \pm 8$ & $4 \pm 3$ \\
\hline Total & 100 & 99 & 100 & 99 & 99 \\
\hline
\end{tabular}

\section{Denning Habitat Suitability}

There are areas of suitable denning habitat predicted in and near VOYA (Fig. 13), but there is less suitable denning habitat than in NE MN where lynx were seen more frequently, and where radiocollared lynx had established home ranges (Moen et al., 2008a). Many of the confirmed and unconfirmed reports of lynx within or near VOYA region are in areas that are predicted to be suitable denning habitat (Fig. 13). The actual den site area required is small (Moen et al., 2008a), however, and it is likely that snowshoe hare availability is more important in limiting lynx presence than den site availability.

Figure 13. Predicted suitable denning habitat in northeastern Minnesota and VOYA (Moen et al., 2008a). Darker areas have more suitable denning habitat based on den site locations. Recent lynx sightings in and near VOYA are shown. Green circles are confirmed (DNA or photograph), yellow circles are not confirmed.
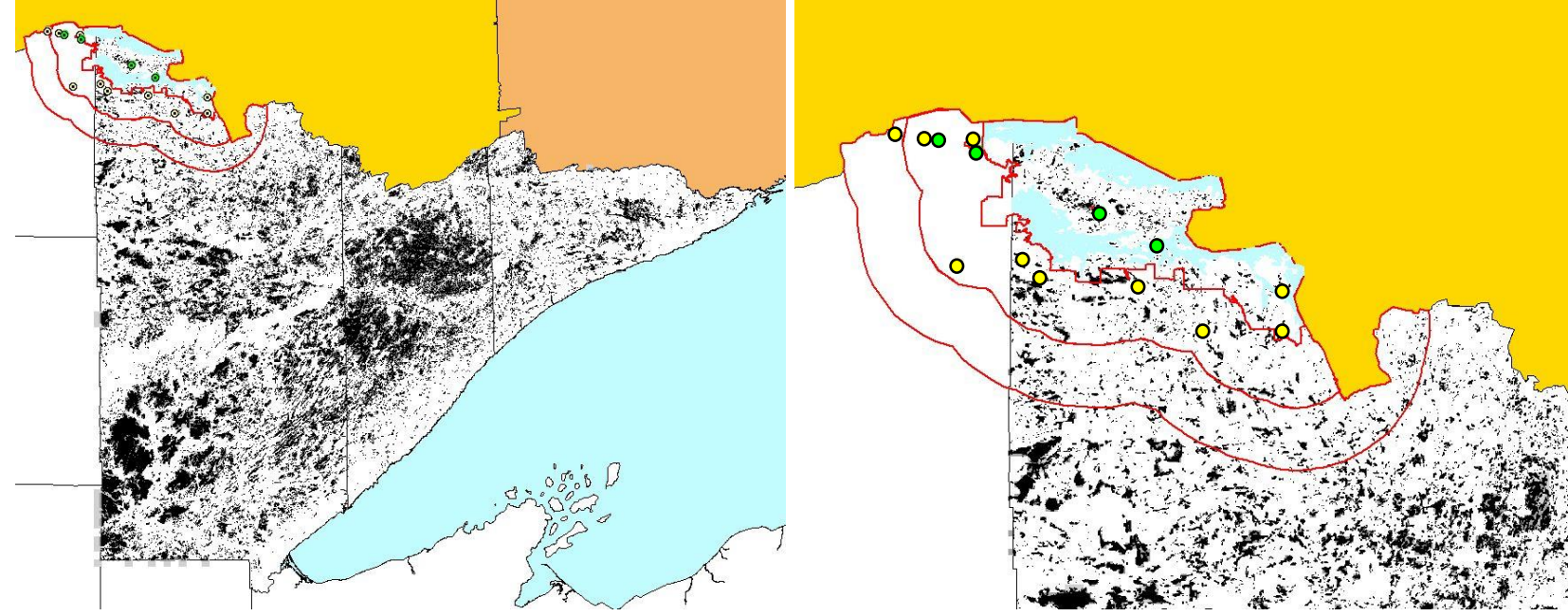


\section{Potential Home Ranges}

Home range care areas of lynx radiocollared in the Superior National Forest were about $50 \mathrm{~km}^{2}$ for males, and about $25 \mathrm{~km}^{2}$ for females (Burdett et al., 2007). Using these approximate sizes, it would be possible to there would be 1 or 2 male home ranges on the Kabetogama peninsula, and 1-2 more in the area south of the VOYA (Fig. 14). About twice as many female home ranges could potentially fit in the area analyzed in this report. These numbers are based on the assumption that habitat quality (prey density) would be similar in VOYA, and thus would represent a maximum number of lynx that would be expected to be present in and near VOYA. Given the measured prey density discussed in the sections above, the maximum number would not be realized at this time.

Figure 14. Approximate size of lynx home ranges (male and female) relative to the Kabetogama Peninsula on Voyageurs National Park.

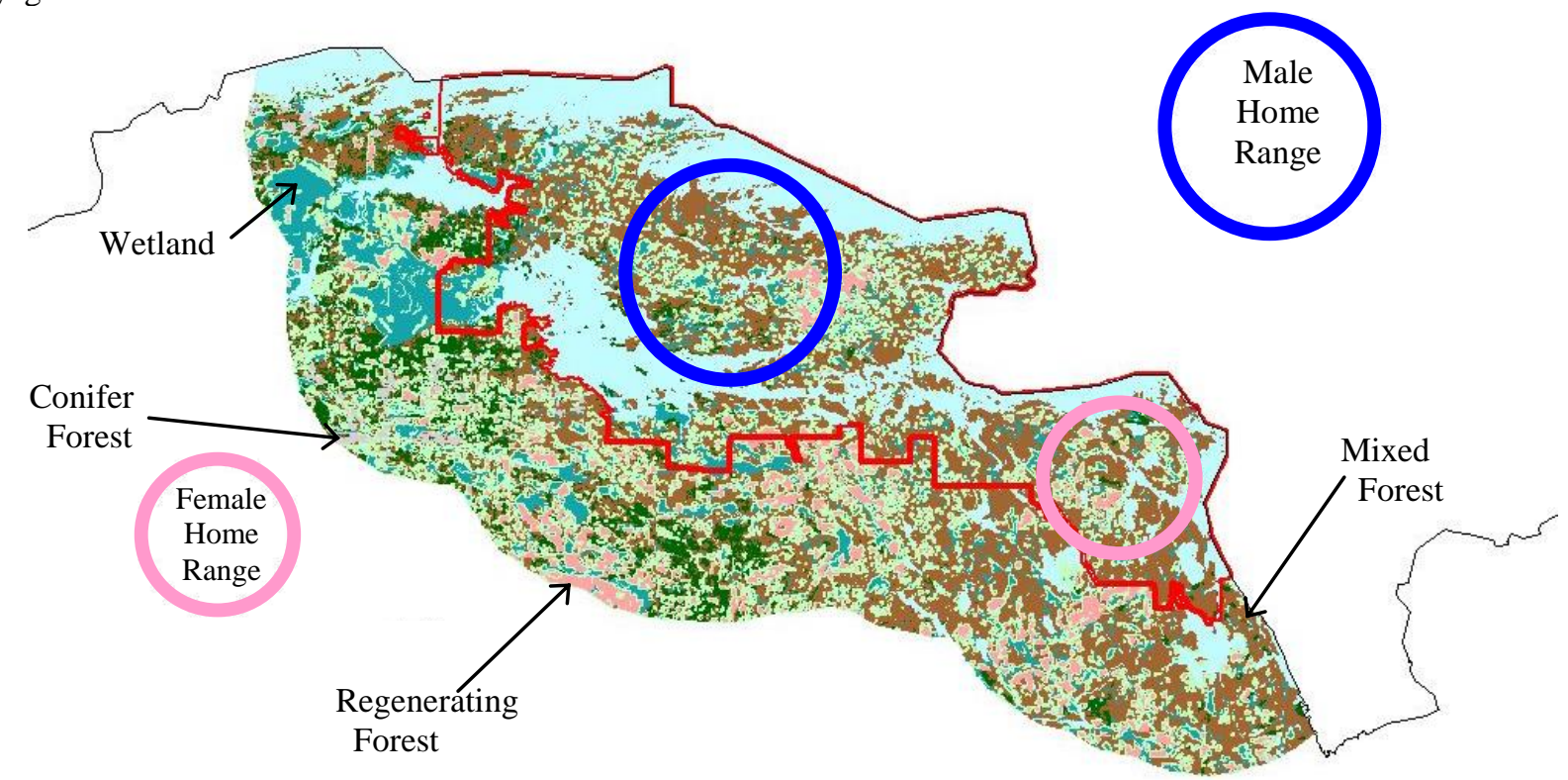

\section{Discussion}

There have been occasional reports of lynx in and near VOYA from 2004 to the present (Route et al., 2009), although we did not detect lynx during this project. Lynx reports are often visual sightings that can not be confirmed by DNA analysis or track identification by a VOYA biologist. However, there have been some confirmed lynx reports in and near VOYA since 2000. A female lynx was confirmed west of VOYA in 2004, near other unverified sightings in 2003 and 2005 (Fig. 13). Trail camera photographs were taken (see front cover) and tracks were seen in the same area for approximately three weeks during the 2009 breeding season (Steve Windels, pers. obs.). However, given the search effort over the past years 
it is likely that there are no resident lynx in VOYA, and that lynx seen on and near VOYA are probably transient animals

If lynx that are seen are transient, they very likely arrived from adjacent parts of Ontario. Many lynx that were radiocollared in the Superior National Forest telemetry study moved back and forth between Minnesota and parts of Ontario west of Thunder Bay. Similarly, lynx could move between VOYA and Ontario, and there should be a source population in Ontario for the foreseeable future. Historical records (Fig. 1) document lynx presence in much of Minnesota, but many of these observations were during what have been termed "lynx invasions" after a hare population crash in Canada (Mech, 1973; Adams, 1963; McKelvey et al., 2000; Henderson, 1978).

Snowshoe hare density within VOYA and the surrounding area is lower than hare density within composite lynx home ranges from the telemetry study. If the habitat changes in or around VOYA so that snowshoe hare populations increase, it is probable that lynx will reappear in VOYA and possibly persist. Hare populations will be able to increase if an adequate conifer component is present in the regenerating forest following disturbance. Continued monitoring of the hare population in different cover types will enable prediction of when the probability of lynx presence in VOYA will increase.

The low predicted hare density in the VOYA area results from a combination of low prevalence of quality snowshoe hare cover types and by a lower density of snowshoe hares within cover types that are present relative to those found in lynx core areas. In the lynx home range core areas where the Superior National Forest telemetry study occurred, disturbance has been caused mainly by forest harvest over the past 30 years. There is little of this cover type in VOYA because disturbance has been minimal over the past 80 years. Most VOYA forests experienced intensive timber harvest in the period 1870-1970 and large, stand-replacing fires burned as much as $25 \%$ of the park in 1923 and 1936 (Faber-Landendoen et al. 2007). There have been no major fires since 1936 due to fire suppression policies and no timber harvest has occurred since the park was established in 1972. Most of the forest stands in VOYA are therefore 30-80 years-old or more.

Hare pellet counts are highest in the Regenerating Forest cover type in the Superior National Forest radiotelemetry study (Moen et al., xxxx; McCann, 2006. A second factor that resulted in lower predicted hare density in VOYA was the reduced density of snowshoe hare within the regenerating forest cover type in the $10 \mathrm{~km}$ and $20 \mathrm{~km}$ buffer strips around VOYA. Regenerating forest had an average of only 0.5 pellets $/ \mathrm{m}^{2}$ near VOYA (Table 5), while within the lynx home range area mean hare pellet density was over 1.5 pellets $/ \mathrm{m}^{2}$ when lynx were radiocollared (Moen et al., 2008b). Both 
Regenerating forest and Conifer cover types would need to have conifer in the understory in order for snowshoe hare density to increase. Snowshoe hare use the conifer understory as escape cover.

We evaluated hare pellet density at the scale of a foraging bout, daily movement of a lynx, and also at the scale of a core area. At all of these spatial scales hare pellet density in VOYA was less than half of the hare pellet density in lynx home ranges in the Superior National Forest study area. Another possible measure of habitat quality is denning habitat. VOYA has potential denning habitat scattered across the park, although at lower densities than denning habitat is found within lynx home ranges. However, it is likely that prey availability (also included in denning habitat) will be more limiting to lynx presence than finding denning habitat.

Based on data from northeastern Minnesota, the presence or density of roads and trails have mixed effects on lynx habitat quality (Terwilleger and Moen in prep). Many GPS collar locations of lynx from the northeastern part of the state are along highways and gravel roads. Lynx likely use roads and trail corridors to increase their efficiency of movement. Even though movement is more efficient, use of roads and trail corridors by lynx may increase risk of mortality from vehicle accidents, incidental trapping, or poaching. Some lynx appear to be able to survive on relatively busy roads, crossing highways and smaller roads multiple times per week within the Superior National Forest lynx home ranges. Without further study, the net effect of roads and trails within VOYA and in the adjacent landscape on overall lynx habitat quality is unclear.

\section{Management Implications}

Minnesota lies at the southern extent of Canada lynx range in North America. Canada lynx have likely been present in Minnesota, including the area that is now Voyageurs National Park, since at least the time of the first European explorers. We did not detect the presence of lynx in or near VOYA during the project period from 2007-2008. There are multiple confirmed records of lynx in the VOYA area since 2000, including one in 2009, however there is no evidence that any of these lynx were residents.

Denning habitat for lynx is generally less abundant in the VOYA area than in the core of Minnesota's lynx range but we believe that sufficient denning cover exists in the VOYA area to support at least several resident lynx. We therefore contend that the most likely factor affecting lynx abundance or residence in the VOYA area is the lack of quality prey habitat. Our analysis suggests that snowshoe hare density for most cover types is lower in the VOYA area than in core parts of lynx range in the northeastern part of Minnesota. This general lower prey density is compounded at the 
landscape-level because cover types with the highest densities of lynx are also less abundant in the VOYA area than in core parts of lynx range in Minnesota.

Landscape-level changes in lynx habitat, primarily in terms of prey abundance, will likely be required to provide the amount of quality lynx habitat that could support resident lynx in the VOYA area. Sufficient amounts of two cover types in particular, conifer forest and regenerating forest, appear to be requisite for resident lynx. Within the park's boundaries, only major disturbances such as blowdowns, insect outbreaks, or stand-replacing fires across large areas (i.e., 1,000's of ha) will be able to create the dense understory structure of the regenerating forest cover type preferred by snowshoe hares and Canada lynx over the next 10-30 years. Conversely, current forest management practices in areas adjacent to the park have created regenerating forest in similar proportions to those in core lynx range.

The conifer forest cover type currently comprises only 1-3\% of the landscape in VOYA area, both inside and outside of the park boundary, an amount considerably less than that found in the core parts of the lynx range in Minnesota. In contrast to the regenerating forest cover type, creation of additional conifer forest in the VOYA area is unlikely over the next 30 years, either through active management or natural processes. This cover type represents mature forest (i.e., $>50$ years old) comprised predominantly of conifer species such as white spruce (Picea glauca) or balsam fir (Abies balsamea) in mesic sites and black spruce (Picea mariana) in poorer sites.

The predominant LULC cover type in the VOYA area is mixed forest on mesic soils. Much of this cover type is comprised of 40-100 year old southern boreal forest with co-dominant white spruce, balsam fir, and trembling aspen (Populus tremuloides). In the absence of stand-replacing disturbance, these stands will succeed towards the spruce-fir dominated climax phase of this forest type within another 50-100 years. Large wind events can also create conifer dominated stands in a somewhat shorter time frame, though this is an unlikely event. A large natural blowdown event occurred in the border region surrounding Boundary Waters Canoe Area Wilderness in 1999 in which the majority of the canopy trees were snapped off in many deciduous dominated stands. The removal of overstory allowed advanced generation of spruce and fir in the understory to dominate and these stands will likely have a conifer dominated canopy in $<20-40$ years.

In contrast to climax boreal forest types, the amount of lowland conifer presently on the landscape in the VOYA area has remained largely unchanged for the last 150+ years, with the majority of such stands in a climax condition. Creation of additional lowland conifer forest can therefore only be achieved by artificial conversion of other vegetation types to lowland conifer. Black spruce and lowland 
white cedar (Thuja occidentalis) dominated forests are mostly limited to poorly drained sites with wetmoist soil conditions. Suitable wetland sites could be planted with black spruce to create conifer dominated forest in 75-100 years. White cedar, a favorite winter browse of white-tailed deer ( Odocoileus virginiaus) in winter, is an impractical choice for planting without considerable investment in protection from browsing.

\section{Acknowledgements}

Funding for this research was provided to VOYA through the National Park Service Biological Resource Division Competitive Grant program. We would like to thank field workers Brice Hansen, Danielle Eithier, Josh Sayers who logged many hours searching for lynx tracks and monitoring cameras. The University of Minnesota Duluth Integrated Biological Sciences graduate program provided support to Brice Hansen for some of his graduate work. The ongoing lynx radiotelemetry project on the Superior National Forest also provided important comparative data which we were able to leverage to make this report a stronger product.

\section{Literature Cited}

Temporary put like this. (Hansen, 2009)

\section{Literature Cited}

Adams,A.W., 1963. The lynx explosion. North Dakota Outdoors 26:20-24.

Aubry,K.B., Koehler,G.M., and Squires,J.R. 2000. Ecology of Canada lynx in southern boreal forests. Pages 373396 in Ruggiero,l., Aubry,K.B., Buskirk,S.W., Koehler,G.M., Krebs,C.J., McKelvey,K.S., Squires,J.R. editors. Ecology and conservation of lynx in the United States. University Press of Colorado, Denver, CO.

Brand,C.J., Keith,L.B., Fischer,C.A., 1976. Lynx responses to changing snowshoe hare densities in central Alberta. J. Wildl. Manage. 40:416-428.

Burdett,C.L. 2007. Hierarchical structure of Canada lynx space use and habitat selection in northeastern Minnesota.University of Minnesota, Twin Cities.

Burdett,C.L., Lindquist,E.L., Moen,R.. National Interagency Canada Lynx Detection Survey in Minnesota, Wisconsin, and Michigan 23. NRRI/TR-2006/37. 2006. Natural Resources Research Institute.

Ref Type: Report

Burdett,C.L., Moen,R., Niemi,G.J., Mech,L.D., 2007. Defining Canada lynx home range and space use with GPS telemetry. Journal of Mammalogy 88:in.

Elton,C., Nicholson,M., 1942. The ten - year cycle in numbers of the lynx in Canada. J. Anim. Ecol. 11:215-244.

Erlinge,S., 1979. Adaptive significance of sexual dimorphism in weasels. Oikos 33:233-245.

Hansen,B. 2009. Factors affecting passive infrared cameras and their use in determining carnivore habitat selectivity based on presence and visitation rates.University of Minnesota, Minneapolis, MN. 
Hanson,K., Moen,R.A.. Diet of Canada lynx in Minnesota estimated from scat analysis. NRRI/TR-2008/13, 1-15. 2008. Natural Resources Research Institute.

Ref Type: Report

Henderson,C., 1978. Minnesota Canada Lynx report, 1977. Minn. Wildl. Res. Q. 38:221-242.

Keith,L.B., 1978. A demographic analysis of the snowshoe hare cycle. Wildl. Monogr. 58.

Krebs,C.J., Boutin,S., Boonstra,R., 2001. Ecosystem dynamics of the boreal forest. Oxford University Press, Inc., New York.

McCann,N. 2006. Using pellet counts to predict snowshoe hare density, snowshoe hare habitat use, and Canada lynx habitat use in Minnesota.University of Minnesota Duluth.

McCann,N., Moen,R., 2010. Using pellet counts, GIS, and satellite imagery to predict snowshoe hare and Canada lynx habitat-use. In preparation.

McKelvey,K., Aubry,K.B., and Ortiz,Y.K. 2000. History and distribution of lynx in the contiguous United States 862. Pages 207-264 in Ruggerio,L.F., Aubry,K.B., Buskirk,S.W., Koehler,G.M., Krebs,C.J., McKelvey,K.S., Squires,J.R. editors. Ecology and conservation of lynx in the United States. University Press of Colorado, Denver, $\mathrm{CO}$.

McKelvey,K.S., McDaniel,G.W., Mills,L.S., Griffin,P.C., 2002. Effects of plot size and shape on pellet density estimates for snowshoe hares. Wildl. Soc. Bull. 30:751-755.

Mech,L.D., 1973. Canadian lynx invasion of Minnesota. Biol. Cons. 5:151-152.

MN DNR. LandSat-Based Land Use-Land Cover. http://deli.dnr.state.mn.us/metadata.html?id=L250000112101 [Accessed 7/28/2009]. 1998. Minnesota DNR - MIS Bureau.

Ref Type: Electronic Citation

Moen,R.. Canada Lynx in the Great Lakes Region 2008 Annual Report. NRRI Technical Report No.NRRI/TR2009-06, 1-34. 2009.

Ref Type: Report

Moen,R., Burdett,C., Niemi,G.J., 2008a. Movement and habitat use of Canada lynx during denning in Minnesota. Journal of Wildlife Management.

Moen,R., Niemi,G.J., Burdett,C.L.. Canada Lynx in the Great Lakes Region Final Report. NRRI Technical Report No.NRRI/TR-2008-14, 1-31. 2008 b.

Ref Type: Report

Murray,D.L., Roth,J.D., Ellsworth,E., Wirsing,A.J., Steury,T.D., 2002. Estimating low - density snowshoe hare populations using fecal pellet counts. Can. J. Zool. - Rev. Can. Zool. 80:771-781.

O'Donoghue,M., Boutin,S., Krebs,C.J., Hofer,E.J., 1997. Numerical responses of coyotes and lynx to the snowshoe hare cycle. Oikos 80:150-162.

Poole,K.G., 1994. Characteristics of an unharvested lynx population during a snowshoe hare decline. J. Wildl. Manage. 58:608-618.

Route,B., Windels,S.K., Schaberl,J.. Status of Canada lynx in Voyageurs National Park, Minnesota, 2000-2004. 2009/172, 1-27. 2009. Fort Collins, CO, National Park Service. Natural Resources Technical Report NPS/GLKN/NRTR.

Ref Type: Report 
Slough,B.G., Mowat,G., 1996. Lynx population dynamics in an untrapped refugium. J. Wildl. Manage. 60:946-961.

Soisalo,M.K., Cavalcanti,S.M.C., 2006. Estimating the density of a jaguar population in the Brazilian Pantanal using camera-traps and capture-recapture sampling in combination with GPS radio-telemetry. Biological Conservation 129:487-496.

Squires,J.R., McKelvey,K.S., RUGGIERO,L.F., 2004. A snow-tracking protocol used to delineate local lynx, Lynx canadensis, distributions. Canadian Field-Naturalist 118:583-589.

Zielinski,W.J., Kucera,T.E.. American marten, fisher, lynx and wolverine: Survey methods for their detection. U.S.D.A.Forest Service General Technical Report PSW-GTR-157, 1-164. 1995.

Ref Type: Generic 


\section{Appendix 1. LULC and USGS VegMap cover type comparison}

Steve: I need to talk with you about this section and how you would use it. 


\section{Appendix 2. Deliverables Listing}

The Original Scope of Work stated that "A final report to Voyageurs National Park will summarize results from the study. Four main products from this report will allow VOYA managers to fulfill obligations to manage federal lands considering the federally-threatened Canada lynx.” This document (NRRI Technical Report 2009/19) is the Final Report. The status of the four main products is indicated below with respect to meeting the Scope of Work requirements.

1. Map/GIS layer of potential lynx habitat based on Superior National Forest results

The best map of lynx habitat in VOYA is based on hare density. Based on hare pellet counts there are no areas of excellent lynx habitat in VOYA at this time. We have also provided a map of suitable denning habitats, but without an adequate prey base it is unlikely that there will be resident lynx in VOYA or the adjacent area.

2. Information on numbers and distribution of Canada lynx and other carnivores of interest in and adjacent to VOYA

Numbers and distribution of Canada lynx was documented with the camera protocol and with the snowtrack searching. Other carnivores of interest were captured on camera and are being analyzed in an M.S. thesis by Brice Hansen (2009).

3. Documentation of home range size, residency, and reproductive activity in VOYA

Since no resident lynx were found this deliverable is not applicable.

4. Analysis of habitat use within VOYA boundaries based on GPS telemetry data

Since no resident lynx were found this deliverable is not applicable.

The following digital data will be delivered to VOYA.

5. Shapefiles used for LULC - USGS VegMap comparison

6. Hare plot shapefiles with pellet counts as fields

7. Camera station locations with picture data.

8. Snow-tracking shapefile

9. LULC coverage clipped to the $20 \mathrm{~km}$ boundary used as a buffer 